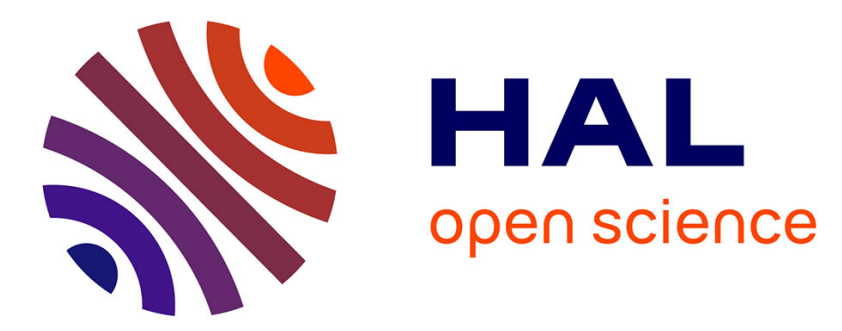

\title{
Malignant Mesothelioma: Mechanism of Carcinogenesis
}

Agnes B Kane, Didier Jean, Sakari Knuutila, Marie-Claude Jaurand

\section{To cite this version:}

Agnes B Kane, Didier Jean, Sakari Knuutila, Marie-Claude Jaurand. Malignant Mesothelioma: Mechanism of Carcinogenesis. Occupational Cancers, Springer London, pp.299-319, 2014, 10.1007/978-14471-2825-0_17. inserm-02479963

\section{HAL Id: inserm-02479963 https://www.hal.inserm.fr/inserm-02479963}

Submitted on 14 Feb 2020

HAL is a multi-disciplinary open access archive for the deposit and dissemination of scientific research documents, whether they are published or not. The documents may come from teaching and research institutions in France or abroad, or from public or private research centers.
L'archive ouverte pluridisciplinaire $\mathbf{H A L}$, est destinée au dépôt et à la diffusion de documents scientifiques de niveau recherche, publiés ou non, émanant des établissements d'enseignement et de recherche français ou étrangers, des laboratoires publics ou privés. 


\section{Mechanism of mesothelial carcinogenesis}

5 Agnes B. KANE ${ }^{1}$, Didier JEAN ${ }^{2,3}$, Sakari KNUUTILA ${ }^{4,5}$, Marie-Claude JAURAND ${ }^{2,3}$.

${ }^{1}$ Department of Pathology and Laboratory Medicine, Brown University, Providence, RI, U.S.A.

$8 \quad{ }^{2}$ INSERM, UMR-S 674, Paris, F-75010, France.

$9 \quad{ }^{3}$ Université Paris Descartes, Sorbonne Paris Cité, UMR-S674, Paris, F-75010, France.

$10{ }^{4}$ Department of Pathology, Haartman Institute and HUSLAB, University of Helsinki, Helsinki, Finland.

$11 \quad{ }^{5}$ Helsinki University Central Hospital, Helsinki, Finland.

13 Corresponding author: Marie-Claude JAURAND - INSERM U674 - 27, rue Juliette Dodu - 75010

14 PARIS - FRANCE

15 Phone: +33153725188 - Fax: +33153725192 - Email: marie-claude.jaurand@inserm.fr

16 


\section{Introduction}

Our present knowledge of the mechanism of mesothelial carcinogenesis results from pathophysiological and toxicological research carried out in vivo in rodents, in mammalian cells in culture, and from biological and molecular studies of malignant mesothelioma (MM) tissue samples and cell lines from humans and experimental animals. In this latter context, most experimental studies have been based on the cellular and/or animal responses to asbestos fibers and in genetically modified mice. These investigations have provided a body of data on the cellular and molecular effects of asbestos fibers on mesothelial cells and the mesothelium, including genomic and genetic changes, and alterations of regulatory and signaling pathways. Human MM has been characterized at the genomic, genetic, epigenetic, and physiological levels, with the development of large-scale analyses allowing global integration of the networks involved in transformation of the mesothelial cell. The aim of the present work is to propose a potential mechanism of mesothelial carcinogenesis by integrating data based on cellular and molecular effects of asbestos fibers on mesothelial cells, with altered physiological and molecular features of malignant mesothelioma cells.

\section{Mechanism of action of asbestos fibers}

\section{a. Translocation}

The initial route of entry of asbestos fibers is by inhalation and deposition in the tracheobronchial regions, distal airways, and alveolar spaces of the lungs 
is slower and mediated by phagocytosis by alveolar macrophages. Fiber length impairs macrophage-mediated clearance, especially for fibers that exceed the diameter of alveolar macrophages $(10-25 \mu \mathrm{m})$. Impaired clearance may result in penetration of fibers through the alveolar epithelium and subsequent translocation to the pleura and distant sites [2]. Fibers that enter the interstitium may cross the visceral pleural by paracellular migration or by direct penetration [3]. An alternative route of translocation to the pleural space is transport via lymphatics or the bloodstream [4].

The parietal pleura lines the chest wall and the superior surface of the diaphragm and the visceral pleura covers the lungs. The pleural space in humans is lined by a single layer of mesothelial cells approximately $1 \mu \mathrm{m}$ thick resting on a basement membrane and underlying connective tissue and blood vessel [5]. The major route of drainage of fluid, protein, particulates, and cells from the pleural space is lymphatic stomata that open between mesothelial cells on the parietal pleural lining [6,7]. The diameter of lymphatic stomata $(\sim 10-12 \mu \mathrm{m})$ limits clearance of long fibers from the pleural space [4].

Systemic dissemination of fibers through lymphatics and the blood stream has been described in humans following autopsy [8-10]. Asbestos fibers and asbestos bodies have been noted in the liver, mesentery, spleen, and abdominal lymph nodes $[11,12]$. Diffuse peritoneal malignant mesothelioma is also associated with exposure to asbestos fibers $[13,14]$; fibers may reach the peritoneal mesothelial lining via diaphragmatic lymphatics that connect 
the pleura and peritoneal spaces or following systemic vascular and lymphatic dissemination.

As this volume is devoted to occupational cancer, the studies reported here will focus on asbestos as the only known etiological factor associated with MM. However, other types of fibers are associated with MM following environmental exposure, and other fibers used for industrial or commercial applications have been found to produce $\mathrm{MM}$ in animals, including manmade mineral fibers and more recently carbon nanotubes. Their effects will be discussed separately in subsequent paragraphs related to the fiber parameters related to carcinogenicity (see paragraphs in 22-2.c).

i. Effects of asbestos fibers in animals asbestos exposure. Nevertheless, no history of exposure can be found in about $10-20 \%$ of $\mathrm{MM}$ cases [15-18]. This relationship between mesothelioma and asbestos has also been well demonstrated by numerous experimental studies carried out in rodents. It must be noted that in animals, other types of fibers also induce MM. Some samples of asbestos fiber substitutes, refractory ceramic fibers (RCF) and glass fibers have induced MM after inhalation by rats or hamsters. These data have been described in detail in several IARC monographs, and summarized in peer reviews [19]. illustrated the carcinogenic potency of these mineral fibers. Both types of exposure have been used to assess fiber parameters modulating the 
oncogenic response in the pleura. It can be emphasized here that fiberinduced MM show similar morphological features in rodents as in humans [20-23].

Some studies have investigated pleural responses to asbestos fibers after deposition in the lung. An inflammatory reaction characterized by the recruitment of inflammatory cells and the presence of growth factors in the pleural fluid was demonstrated [24]. These growth factors were able to induce proliferation of mesothelial cells in culture. This inflammatory response may be triggered by fiber translocation to the pleura as demonstrated in rodents exposed to glass fibers or to RCF $[25,26]$. Several studies have demonstrated the presence of asbestos fibers in the human pleura $[9,10,27]$. Hypotheses on the mechanism of asbestos translocation have been recently discussed [3,4] (see paragraphs 22.2.a).

Several fiber parameters are of importance in the mechanism of asbestos toxicity. They are discussed in paragraphs 22-2.c. In animal experiments, it was generally found that the fiber dimensions were important, with a greater carcinogenic potency of long and thin fibers in comparison with shorter fibers.

Mutations in malignant mesotheliomas have been investigated in animals, after in vivo exposure to asbestos fibers. Table 22-1 summarizes genomic alterations in MM identified in asbestos-exposed animals. Although few studies have been performed, these results are consistent with observations made in human MM. Chromosome rearrangements were observed in wildtype animals exposed to asbestos. Mutations and base hydroxylation have 
been detected within several weeks after asbestos administration. At the gene level, no or few mutations were found in the tumor suppressor gene (TSG) Tumor protein p53 (Trp53), both in wild-type rats and heterozygous NF2 mice. Interestingly, genes at the Ink $4 a$ locus were deleted, as found in human MM. In MM from genetically modified mice, gene inactivation occurred by loss of heterozygosity ( $\mathrm{LOH})$. These studies suggest that asbestos fibers are genotoxic, and can produce DNA strand breaks and chromosomal recombination.

ii. Effects of asbestos fibers on mesothelial cells in culture.

While early studies have been carried out with cells of different species and tissues, rat and human mesothelial cells have been most widely used to study the response of mesothelial cells to asbestos fibers. Detailed data can be found in a several reviews $[28,29]$.

Various types of asbestos fibers have been found to cause cytotoxic and genotoxic defects in primary cell cultures and in animals exposed to fibers [30]. Typically, chromosomal breaks, centromeric and telomeric alterations as well as aneuploidy (an lower number of chromosomes in comparison with normal cells), polyploidy (twice or several times the normal number of chromosomes) and heteroploidy (an abnormal number of chromosomes) due to spindle defects, are seen. Because of chromosomal breaks, as well as spindle and centrosomal damage, micronucleus formation is a typical feature of asbestos-induced genotoxicity, whereby genotoxic endpoints are quantitated by scoring the number micronuclei [31]. 
Table 22-2 summarizes genomic alterations in mesothelial cells in culture treated with asbestos fibers. Briefly, when exposed to asbestos fibers, mesothelial cells demonstrate phagocytic properties. Within hours, responses to oxidant stress, activation of the Mitogen-Activated Protein Kinase (MAPK) pathway, and induction of transcription factors are detected. Table 22-3 summarizes activation of various signaling pathways in mesothelial cells in culture exposed to asbestos fibers. When incubated in the absence of serum or in low levels of serum concentration, cell proliferation was observed [32,33]. In proliferating mesothelial cells, asbestos provoked a p53- and p21-dependent cell cycle arrest consistent with the induction of a DNA damage-induced response [34]. P53 was also induced in serumdeprived G0 synchronized mesothelial cells exposed to asbestos, but failed to block cell cycle progression [35]. However, genotoxicity was also found suggesting that the DNA repair mechanism was incomplete, error-prone, or impaired.

Several types of genetic damage have been found in asbestos-exposed mesothelial cells (Table 22-2). Briefly, DNA damage was demonstrated directly by the occurrence of DNA breakage [36-39], and indirectly by the induction of DNA repair $[40,41]$. Oxidation of deoxyguanosine has been reported in several studies. Notably, recurrent chromosome abnormalities have been reported. These consist in numerical and structural changes, including aneuploidy and polyploidy, micronucleus formation, and chromosomal missegregation [42-48]. Comparison between different studies showed that significant effects were found with doses of $0.5-1 \mu \mathrm{g} / \mathrm{cm}^{2}$ [29]. 
These studies demonstrate that asbestos fibers are genotoxic for mesothelial cells, able to produce base hydroxylation, DNA breakage, and numerical and structural chromosomal changes in mesothelial cells. DNA repair processes are stimulated in asbestos-treated mesothelial cells. The consequences of DNA damage will be dependent on the efficiency and fidelity of repair. When genomic damage is extensive, an apoptotic program should be induced. As discussed previously, life-or-death decisions may be at the heart of malignant transformation and defective mechanisms of arrest or apoptosis may be critical to development of malignancy [49]. Several studies with mesothelial cells in culture have emphasized the occurrence of apoptosis, which should be beneficial for the mesothelium. However, some cells can survive with gene alterations that can be inherited in daughter cells. In that context, it is remarkable that mesothelial cells show both cell cycle arrest and mitotic abnormalities, suggesting that the cells could pass through cell cycle checkpoints with unrepaired DNA and chromosomal damage. According to our knowledge, no data on epigenetic changes in asbestosexposed cells in culture, or in animals have been reported. Further investigations would be of great interest for our understanding of the mechanism of action of asbestos fibers in carcinogenesis. mice exposed to mineral fibers. One study was based on mice carrying a heterozygous mutation in the TSG $\operatorname{Trp} 53\left(\operatorname{Trp} 53^{+/-}\right)$, and others on mice 

obtained from $\operatorname{Trp}_{5} 3^{+/-}$mice exhibited Trp53 LOH and polyploidy [50]. LOH of the $N f 2$ gene was found in $N f 2^{+/-}$mice suggesting a common mechanism for loss of the wild type (WT) allele [23,51]. Moreover, in $\mathrm{NF}^{+/-}$ mice, two other TSG, cyclin-dependent kinase inhibitor $2 \mathrm{a}(p 16 / c d k n 2 a)$ and cyclin-dependent kinase inhibitor $2 \mathrm{~b}(\mathrm{p} 15 / \mathrm{cdkn} 2 \mathrm{~b})$ were deleted at a high rate, similar to human MM, while $\operatorname{Trp} 53$ was mutated at a much lower rate $[51,52]$. In studies carried out by one of us (MCJ), $N f 2$ and $\operatorname{Trp53}$ were exclusively inactivated. Spontaneous MM in the absence of asbestos exposure have been generated in double mutants $\mathrm{Nf2^{+/- }} ; \mathrm{Trp}_{53^{-/-}}$and $\mathrm{Nf2^{+/- }}$ ;Ink4a/Arf ${ }^{/-}$mice. MM developed rapidly and at a high incidence [53]. These results suggest that MM development can be associated with inactivation of TSG involving several pathways including Trp53 or $N f 2$ and genes at the Ink $4 a$ locus, the two latter genes being more specific targets of asbestos effects. Murine MM closely mimicked the human disease characterized by peritoneal ascites, a long latency between fiber injection and $\mathrm{MM}$ development, and histological subtypes, epithelioid, sarcomatoid and biphasic, similar to human MM. The results obtained with genetically modified mice show that MM progression could follow several routes involving different TSG, and are in good agreement with (i) specific clinical features and molecular alterations in human MM, and (ii) the role of tobacco smoke in cancer development. It is generally accepted that MM is not related to smoking, and that p53 mutation is a signature of tobacco smoke, consistent with no signature of tobacco smoke in MM development. 
page $10 / 72$

Nevertheless, this strongly suggests that other carcinogens targeting p53 that could reach the pleura would be able to induce MM.

This chapter will discuss the biological mechanisms leading to development of diffuse malignant mesothelioma focusing on the physiochemical properties of asbestos fibers, carbon nanotubes, and other engineered high aspect ratio nanomaterials relevant for the pathogenesis of this cancer. The reader is referred to the comprehensive reviews cited above for a detailed summary of the toxicological studies related to biological activity of carbon nanotubes.

\section{i. Mineral fibers}

Asbestos and erionite are naturally-occurring fibrous minerals that have been associated with the development of diffuse malignant mesothelioma in epidemiological studies [54,55]. Asbestos fibers are fibrous silicates and are classified into two groups based on their crystal structure and chemical composition: serpentine asbestos which is called chrysotile and amphibole asbestos which includes crocidolite, amosite, tremolite, actinolite, and anthophyllite [56,57]. Erionite fibers are a form of the mineral zeolite characterized by a high internal surface area [58]. These naturally-occurring fibrous minerals are variable with respect to chemical composition, associated minerals, and trace contaminants depending on their geographic origin [59]. Asbestos fibers may contaminate other mineral deposits, for example, talc [54,60] and vermiculite from Libby, Montana [60,61] and 

fibers associated with biological activity include shape and dimensions, surface chemistry and reactivity, and biopersistence [19].

\section{ii. Shape and dimensions}

Elongated fibers with a high aspect ratio, defined as a length: diameter ratio of 3:1 or greater, are characteristic of the crystalline structure of the mineral. Asbestos fibers occur as bundles of individual crystals or fibrils that split longitudinally at the silicate layers. Fiber length and diameter determine respirability and site of deposition in the lungs and fiber length is related to efficiency of phagocytosis by alveolar macrophages and rate of clearance from the lungs [19].

Titanium dioxide nanorods have been shown to induce frustrated phagocytosis and activation of the Nalp3 inflammasome [63] similar to asbestos fibers [64]. Carbon nanotubes have also been shown to induce frustrated phagocytosis by macrophages in vitro [65]. In rodents, long rigid carbon nanotubes have been shown to translocate to the subpleural regions of the lungs [66-69] and to induce inflammation, frustrated phagocytosis, and granulomas similar to asbestos fibers following intraperitoneal injection [65]. Direct intraperitoneal [70] or intrascrotal injection [71] of some commercial carbon nanotubes induced diffuse malignant mesothelioma in heterozygous p53-deficient mice and wild type rats, respectively. However, short multiwalled carbon nanotubes $(<1 \mu \mathrm{m}$ long $)$ did not induce mesotheliomas in rodents following intraperitoneal injection [72]. 
Serpentine or chrysotile asbestos is a magnesium silicate $\left(\mathrm{Mg}_{3} \mathrm{Si}_{2} \mathrm{O}_{5}(\mathrm{OH})_{4}\right)$; $\mathrm{Mg}^{2+}, \mathrm{Al}^{3+}, \mathrm{Ca}^{2+}$, and $\mathrm{Na}^{+}$. Surface chemistry determines interactions between the fiber, physiological fluids, and cells with possible proton transfer, oxidation-reduction reactions, and adsorption of biological macromolecules [58]. Broken chemical bonds at the fiber surface are highly reactive with molecular oxygen and can generate free radicals in aqueous fluid [73]. Surface $\mathrm{Fe}^{2+}$ and $\mathrm{Fe}^{3+}$ ions on amphibole asbestos fibers are bioavailable and catalyze formation of reactive oxygen species (ROS) [74]. Erionite fibers can acquire $\mathrm{Fe}^{2+}$ and $\mathrm{Fe}^{3+}$ ions and become redox active in the presence of intracellular chelators or reductants such as citrate or ascorbate [75]. Iron-catalyzed redox activity has been associated with biological effects of mineral fibers including lipid peroxidation, oxidative DNA damage, and activation of intracellular signaling pathways [76,77].

Genotoxicity of natural and man-made fibers has been linked with surface reactivity, especially redox activity, as detected using acellular assays for free radical generation [78], induction of micronuclei [28], and mutagenicity using a hamster-human hybrid cell line [79]. Amphibole and chrysotile asbestos fibers show strong activity using these assays, while silicon carbide fibers show no free radical activity [78]. Refractory ceramic fibers contain bioavailable iron and are active in the salicylate assay to detect release of hydroxyl radicals [78]. Chrysotile asbestos fibers, tremolite (an amphibole 
hamster-human hybrid cell line, while refractory ceramic fibers are nonmutagenic [79].

The ability of carbon nanotubes to generate free radicals is controversial. Some commercial carbon nanotube samples have not been shown to generate carbon or oxygen-centered free radicals using spin-trapping and electron spin resonance $[68,80]$. In fact, carbon nanotubes can scavenge hydroxyl and superoxide radicals which has been attributed to defects in the graphene sidewalls creating gaps in the carbon lattice and dangling bonds reverse mutation assays [82]. Agglomerated multiwalled carbon nanotubes are also negative in this assay and do not induce chromosome aberrations in the V79 cell assay [83]. Long multiwalled carbon nanotubes, but not short multiwalled carbon nanotubes or long single-walled carbon nanotubes, induced DNA strand breaks in human lung epithelial cells [84]. Multiwalled carbon nanotubes also induced micronuclei in rat lung epithelial cells in culture and in animals [85]. Single-walled carbon nanotubes, carbon nanofibers, and graphite nanofibers induced micronuclei in V79 cells [86] and human bronchial epithelial cells [87]. Both single-walled and multiwalled carbon nanotubes have been shown to induce oxidative stress, DNA damage, and activation of intracellular signaling pathways in cultures of human mesothelial cells $[88,89]$. amplified by secondary generation of reactive oxygen and nitrogen species 
pleural lining $[76,90]$. Target cells generate endogenous ROS and reactive nitrogen species during the process of phagocytosis [91], disruption of mitochondrial electron transport [77], and activation of inducible nitric oxide synthase generating nitrogen-derived radicals [92]. These exogenous and endogenous reactive oxygen and nitrogen species have multiple effects on target cells in the pleura that amplify the inflammatory response, activate inflammatory cells to release chemokines, cytokines, and other mediators, stimulate cell proliferation, and induce cell injury and apoptosis $[64,76]$. chromosomal damage due to direct physical interference with the mitotic apparatus [28,93] or by binding to cell cycle regulatory proteins [94]. Induction of chromosomal breaks and aneuploidy has been shown for singlewalled carbon nanotubes and carbon nanofibers in V79 cells [86] and for single-walled and multiwalled carbon nanotubes in rat [85] and human [87] lung epithelial cells. These direct physical effects of long, thin fibers on target cells in the lungs and pleura raise concern about potential carcinogenicity of man-made mineral fibers that have been developed as asbestos substitutes [19] or engineered fibrous nanomaterials including carbon nanotubes $[4,95]$ and metal and metal oxide nanorods or nanowires [63]. Although these man-made fibers and engineered nanomaterials may not have intrinsic redox activity, other surface properties (e.g., structural generate oxygen-derived radicals. 
A major determinant of fiber pathogenicity is biopersistence in the lungs [19]. If long fibers are not efficiently cleared or destroyed by physical breakage, splitting or chemical dissolution in the lungs, they are called biopersistent [19]. Differences in biopersistence of asbestos fibers have been linked with carcinogenic potency, as biopersistent fibers could sustain a local inflammatory response [96]. Amphibole asbestos fibers are more potent than chrysotile asbestos fibers due to their increased biopersistence in the lungs. However, fiber biopersistence in the pleura is not documented; in particular, there are no data on the relationship between biopersistence in the lung and translocation of fibers from the lung to the pleura, nor on the pleural clearance of fibers following inhalation $[97,98]$.

Biopersistence of natural and man-made fibers in the lungs [99] or peritoneal cavity [100] is an important characteristic of fibrous materials that induce lung cancer and diffuse malignant mesothelioma in rodents following inhalation [19]. Man-made mineral fibers developed as asbestos fiber substitutes, especially refractory ceramic fibers [26] and silicon carbide whiskers, have been shown to be biopersistent [101] following inhalation by rodents. Following inhalation by hamsters, refractory ceramic fibers translocated to the pleura and induced mesothelial cell proliferation and fibrosis [26]. Refractory ceramic fibers also induced pleural malignant mesotheliomas after chronic inhalation by rats and hamsters [19]. Intrapleural [102] or intraperitoneal injection of silicon carbide whiskers [103] also induced diffuse malignant mesothelioma in rats. Although no malignant mesotheliomas have been reported in worker cohorts involved in 
manufacturing and application of refractory ceramic fibers, the rodent carcinogenicity assays raise concern that long thin biopersistent mineral fibers may be carcinogenic [104]. Erionite fibers are very potent in induction of malignant mesotheliomas following intrapleural injection [105] or inhalation [106].

Natural and man-made fibers are not unique in induction of rodent malignant mesotheliomas following intraperitoneal or intrapleural injection. A variety of chemicals, radionuclides, SV40 virus, and metallic nickel particles are also carcinogenic in this rodent bioassay [107]. From a mechanistic viewpoint, ferric saccharate, nitrilotriacetic acid, nickel particles, and alpha- or beta- emitting radionuclides are notable in their abilities to generate reactive oxygen species [108]. Unfunctionalized carbon nanotubes are bioperistent when assessed in acellular assays [109]; however, carboxylated single-walled carbon nanotubes are susceptible to enzymatic [110] or oxidative degradation [111]. In principle, carbon nanotubes could be engineered to alter their physiochemical properties in order to decrease their biological reactivity and potential carcinogenicity. important properties of engineered nanomaterials that raises concern about their potential to be translocated to and retained in the pleural following 
page $17 / 72$

Additional features of engineered carbon nanomaterials that may alter their biological activity include their purity, rigidity, hydrophobicity, and agglomeration state. Carbon nanotubes are frequently produced commercially in the presence of metal catalysts including nickel, iron, cobalt, and yttrium [113]. Other potential contaminants include combustionderived products such as polycyclic aromatic hydrocarbons [113]. Amorphous carbon residues at the graphenic surface of carbon nanotubes may also contribute to surface reactivity [85]. Bioavailability of metal catalyst residues is variable depending on the purity of carbon nanotubes; redox active metal catalyst residues can generate reactive oxygen species leading to cell toxicity, inflammation, activation of intracellular signaling pathways involving the MAPK and the nuclear factors NF-KB and AP-1 [76], and genotoxicity [95]. Carbon nanotubes can be highly variable in length ranging from $1 \mathrm{~nm}$ to $1 \mathrm{~mm}$. Although short nanotubes and nanofibers less than $5 \mu \mathrm{m}$ in length should be more easily phagocytized and cleared following inhalation [4], they may behave as needles and penetrate into cells and the nucleus where they could directly damage chromosomes and DNA [95]. Unfunctionalized carbon nanomaterials are very hydrophobic and tend to form agglomerates or bundles called nanoropes, although individual carbon nanotubes have been detected in aerosols [114]. Hydrophobic nanomaterials may interact differently with biological macromolecules in comparison with hydrophilic crystalline mineral fibers [115]. Very thin, hydrophobic carbon nanotubes may bend and agglomerate to form spherical 
aggregates that are more readily phagocytized than long, rigid multiwalled carbon nanotubes that have been shown to induce frustrated phagocytosis resulting in impaired clearance and translocation to the pleura $[4,116]$. The extent of agglomeration has also been shown to influence cell toxicity: ropelike agglomerates of carbon nanotubes were shown to be more toxic than crocidolite asbestos fibers using a mesothelioma cell line [115]. Finally, structural defects at carbon nanotube surfaces attributed to imperfections in the graphene lattice or defects leading to surface oxidation and increased hydrophilicity have been shown to contribute to acute toxicity and genotoxicity of even short multiwalled carbon nanotubes [85].

The potential of engineered carbon nanotubes to induce pathological reactions (lung inflammation, fibrosis, and diffuse malignant mesothelioma) similar to asbestos fibers has generated significant controversy and concern for occupational safety and health $[112,117]$. Occupational exposures via inhalation, skin contact, and ingestion are possible during the synthesis, handling, and fabrication steps of engineered carbon nanotubes; airborne mass concentrations in the range of $0.7-430 \mu \mathrm{g} / \mathrm{m}^{3}$ have been detected at eight worksites and research laboratories [118]. Several recent reviews have summarized the numerous in vitro cellular and rodent toxicology studies investigating biological activity and potential toxicity of carbon nanotubes $[90,114,116,118]$.

d. Summary hypotheses on the mechanism of action of asbestos fibers to generate mesothelioma 
Development of diffuse malignant mesothelioma is a complex, multistage process that is governed by the physicochemical properties of crystalline mineral fibers and their propensity to migrate to the pleural and peritoneal linings as summarized in Figure 22-1. The most important properties of asbestos fibers related to carcinogenicity are fibrous shape and dimensions, surface chemistry and reactivity, and biopersistence [19]. Long, rigid biopersistent fibers that are translocated to the pleura are trapped on the parietal pleura lining at the sites of lymphatic openings [27] and incite a persistent inflammatory response [4]. The pleura is covered by a thin, single layer of mesothelial cells that have lower antioxidant defenses than lung epithelial cells [119].

Interactions between mesothelial cells and fibers can cause genetic and chromosomal changes. There is a great body of evidence that 1) asbestos fibers can directly interfere with chromosomes and the mitotic spindle [120122], and 2) that they induce formation of reactive oxygen species (ROS) resulting in DNA breaks, oxidation, and mutations [123]. Further, 3) the physical interaction of fibers with target cells causes persistent inflammation and, consequently, modulation of inflammatory and immune responses. ROS have been clearly indicated to cause genetic damage including chromosomal breaks and mutations [123]; and they are well shown to initiate signal transduction pathways that are, in turn, linked to inflammation, proliferation, and apoptosis [124]. Free radical scavengers have reported to decrease genotoxic endpoints such as micronucleus formation induced by 
fibers [125]. Further, there is clear-cut evidence that antioxidant enzymes can protect cells against genotoxicity induced by chrysotile fibers [126]. Prolonged interaction between pleural inflammatory cells and adjacent mesothelial cells causes persistent release of chemokines and cytokines, inflammatory mediators, reactive oxygen and nitrogen species, and growth factors that trigger repeated episodes of inflammation resulting in mesothelial cell injury, death, and proliferation [127]. In this chronic inflammatory microenvironment, genomic instability and acquired genetic and chromosomal alterations in mesothelial cells may lead to altered cell cycle and growth regulation, resistance to apoptosis [128], impaired repair of DNA and chromosomal damage induced directly or indirectly by asbestos fibers [28,93], and activation of oncogenes and inactivation of tumor suppressor genes [129]. Persistent inflammation has also been linked with altered gene methylation patterns identified in diffuse pleural malignant mesotheliomas in humans [130]. DNA methylation leads to epigenetic gene silencing and has been linked to inflammation-mediated damage to cytosine [131] or endogenous generation of methyl radicals [132]. This persistent inflammatory microenvironment in combination with oxidative stress generates a strong selective force for mesothelial cells that have acquired genetic and epigenetic changes that promote their survival, proliferation, and tumor progression [133].

\section{Mesothelial cells and malignant mesothelioma}

a. The mesothelial cell in situ. Normal cells. 
The mesothelium consists of a monolayer of mesothelial cells lying on a basement membrane and supported by connective tissue stroma containing fibroblasts. Mesothelial cells provide a protective barrier for frictionless interface for the free movement of apposing organs and tissues, and in fluid transport across the pleura [134]. Mesothelial cells may have specialized functions at different anatomical sites, as demonstrated by morphological studies at the ultrastructural level [135]. Mesothelial cells play a role in the resolution of inflammation and tissue repair after pleural injury. Fibrosis is a potential outcome of chronic inflammation. These processes are of particular interest in investigating the mechanism of action of asbestos fibers in the pleura.

So far, the mechanism of mesothelial cell regeneration is poorly understood, mostly in the context of serosal injury following dialysis; however some controversial hypotheses have been formulated. Recent comprehensive reviews summarize our present knowledge of these potential mechanisms [136,137]. The regeneration process mesothelial cells : (i) centripetal migration of adjacent mesothelial cells, (ii) exfoliation of mature or proliferating mesothelial cells that replicate on the wound surface, (iii) pre-existing free-floating serosal cells having the capability to differentiate into new mesothelium, (iv) macrophage transformation into mesothelial cells, (v) submesothelial mesenchymal precursors that migrate to and differentiate at the has been studied experimentally following mechanical, chemical or heat injury of the peritoneal serosa. Briefly, six mechanisms have been suggested to replace the injured mesothelium surface, and (vi) bone marrow-derived circulating precursors [137].

The origin of these new mesothelial cells has not yet been confirmed, but according to Mutsaers et al. [136], mesothelial regeneration is not dependent on subserosal cells, but 
more likely results from implantation, proliferation, and incorporation of free-floating mesothelial cells [138].

\section{b. The malignant mesothelioma cell}

i. Role of gene mutations in the neoplastic transformation of mesothelial $\underline{\text { cells }}$

Carcinogens provoke several types of somatic gene mutations, consisting of DNA and chromosome alterations. Some mutations are the signature of past exposure to one or several given carcinogens. Somatic mutations in tumors are of interest both to determine the mechanism of action of carcinogens, and to elucidate their adverse consequences on cellular homeostasis.

In malignant pleural mesothelioma (MPM), there is a limited number of genes known to be recurrently mutated. Mutations in TSG cyclin-dependent kinase inhibitor 2A $(P 16 / C D K N 2 A)$, an alternative open reading frame of $C D K N 2 A$ generating a distinct protein $(P 14 / A R F)$, cyclin-dependent kinase inhibitor $2 \mathrm{~B}(P 15 / C D K N 2 B)$ and $N F 2$ have been reported in a high percentage of MM, and TP53 (tumor protein p53) has been found mutated at a lower rate in comparison with other human cancers [139-141]. These genes play a role in cell cycle regulation at different levels. The CDKN2A locus encodes two different proteins, $\mathrm{p} 16^{\mathrm{INK} 4 \mathrm{~A}}$ and $\mathrm{p} 14^{\mathrm{ARF}}$ while $P 15 / C D K N 2 B$ encodes one protein $\mathrm{p} 15^{\mathrm{INK} 4 \mathrm{~B}}$. Both $\mathrm{p} 16^{\mathrm{INK} 4 \mathrm{~A}}$ and $\mathrm{p} 15^{\mathrm{INK} 4 \mathrm{~B}}$ are inhibitors of the kinase function of cyclin/cdk complexes involved in cell cycle progression. TP53 encodes a protein, p53, which is activated in response to DNA damage and is a regulator of apoptosis. The protein $\mathrm{p} 14^{\mathrm{ARF}}$ has indirect function on cell cycle regulation, by positively regulating the level of p53 
through interaction with p53 inhibitors. Consequently, cells with damaged DNA can proliferate and survive in the absence of p14 ${ }^{\mathrm{ARF} .}$ Interestingly, all of these genes carry different types of mutations. The most frequent alteration at the $P 16 / C D K N 2 A$ and $P 15 / C D K N 2 B$ loci is homozygous deletion in about $70 \%$ of MM cases [141]. In murine models of asbestosinduced mesothelioma, the orthologous genes, $p 16 / C d k n 2 a$ and $p 15 / C d k n 2 b$, were also inactivated by deletion $[51,52,142]$. It can be also noted that P16/CDKN2A deletions have been considered as a marker of asbestos exposure in a study of non small cell carcinomas [143]. However, in MM, DNA methylation of $P 16 / C D K N 2 A$ and $P 15 / C D K N 2 B$ has been reported at a frequency of 13\% (9 patients) and 4\% (3 patients) respectively, and positively correlated with asbestos body counts in the lung [130,144]. The average methylation frequency of these gene in the literature is about $10 \%$ [52,144-149]. It was also suggested that mesotheliomas express microRNA (miRNA) that could inhibit $P 16 / C D K N 2 A$ expression, based on in silico analysis for miRNA target gene prediction [150].

Point mutations are the main types of alterations of TP53 in MM. Six point mutations are indicated in the IARC p53 database, five missense mutations and one stop mutation [151]. So far, no specific type of mutation in TP53 has been related to asbestos exposure. In lung cancer, G:C-to-T:A transversions are generally interpreted as mutagenic fingerprints of tobacco smoke [152]. This base substitution can be due to the formation of $8-\mathrm{OH}-$ deoxyguanosine generated by oxidative damage, which in turn causes primarily G-to-T transversions. A few studies have reported TP53 mutations 
in relationship to asbestos exposure. In lung cancer, the frequency of mutations was diminished in lung adenocarcinomas of asbestos-exposed subjects in comparison with unexposed patients but the difference was not significant [153]. G-to-T transversions in asbestos-exposed lung cancers have been reported, but not in all studies, and G:C-to-A:T transitions are rare [153].

TP53 mutations reported in MM consisted of different types of base substitution and base deletion but G:C-to-A:T transitions seems to be the most frequent [151] (unpublished data from MCJ). In animal models of MM, the mutated status of $\operatorname{Trp} 53$ was investigated in mice exposed to mineral fibers by intraperitoneal inoculation. In $\mathrm{C} 57 \mathrm{~B} 1 / 6 \mathrm{p} 53^{+/-}$mice, a strain having one allele mutated in the gene Trp53, loss of the wild type allele was found at a high rate in MM induced by asbestos fibers [154]. In $N f 2^{\mathrm{WT}}$ and $N f 2^{+/-}$ FVB mice, Trp53 alterations were infrequent. Two point mutations A:T-to$\mathrm{C}: \mathrm{G}$ were detected in mice exposed to asbestos, and two point mutations, A:T-to-G:C and A:T-to-T:A, and a duplication of 12 bases in MM were found in mice exposed to ceramic fibers $[52,142]$. Frequency of alteration in results suggest that deletions would be more likely a consequence of the mechanism of action of asbestos, while p53 point mutations could be related to "spontaneous" gene alterations in this model. 
NF2 has pleiotropic functions, being involved in regulation in cell proliferation, apoptosis and endocytic trafficking, and acting upstream of the Hippo signaling pathway [160]. Mutations in NF2 consist of both point mutations and deletions [129]. So far, there is no explanation for the high level of alterations in NF2 in MPM. However, some hypotheses can be formulated and will be discussed below (see 4. Concluding remarks).

571 ii. Role of genomic alterations in the neoplastic transformation of mesothelial $\underline{\text { cells }}$

Chromosome banding, fluorescence in situ hybridization, flow cytometry, Southern blotting and chromosome and array comparative genomic hybridization, single nucleotide polymorphism (SNP) array and representational oligonucleotide microarray analysis (ROMA) as well as second generation sequencing analyses all indicate complex genomic alterations in MM [161171]. Typically, chromosomal abnormalities are very complex, even chaotic, that is involving alterations both in chromosome structure and number [161,163-165,172-174]. It is characteristic for this disease that the chromosome number is mostly hypodiploid (less than 46 chromosomes, the normal number of chromosomes in human), but it varies greatly within a specimen, as a given tumor can exhibit a variety of hypodiploid metaphases [161]. Similarly, polyploid forms (with a number of chromosomes twice or more the number of chromosomes present in the parental cell) of the hypodiploid clone are commonly encountered. Other cytogenetic alterations may be observed such as diplochromosomes of endoreduplication which are 
a signature of alteration of the mitotic process. The polyploidization and non-disjunction type of aneuploidy are due to fiber-induced damages to the structures involved in cell division, i.e. the middle spindle, centrosome, centriole, cleavage furrow, and cell membrane. are highly variable. Typically, translocations, deletions, insertions and inversions are seen. Occasionally, double minutes and a homogenously staining region, representing cytological manifestations of gene amplification are also observed. So far, translocations are mainly unbalanced been reported. Due to chaotic nature of these aberrations and methodological difficult in karyotypic analysis. Novel next generation sequencing methods, such as exome sequencing, has facilitated overcoming the above-mentioned problems and, for the first time, fusion genes have been described in MM [169].

These described structural changes are mainly due to DNA breaks. The mechanism known as breakage-fusion-bridge phenomenon nicely explains severe chromosomal imbalances and intratumoral heterogeneity in MM [175]. As already mentioned, asbestos fibers are capable of causing DNA breaks either directly or indirectly through ROS generation. Whether there are hot spots in the genome for DNA breaks caused by fibers is still largely an open question. However, experiments with cells in culture have indicated that chromosome aberrations induced by fibers may be recurrent. Certain 
numerical chromosomal abnormalities have been reported to be overrepresented in human pleural cell cultures exposed to asbestos [176]. Even though no distinct hot spots were seen in this study, chromosome 1 seemed to be involved more often than other chromosomes. Interestingly, we have previously reported that structural aberrations in the short arm of chromosome 1 and loss of material in the short arm chromosomes 1 and 4 were associated with high asbestos fiber burden in MM [177,178]. More recently, one of us (DJ) identified a recurrent region of chromosome loss, 14q11.2-q21, in MM from asbestos-exposed patients that was not found in unexposed patients. The syntenic region that also lost in fiber-induced MM in mice, suggesting that this region might be a target of action of mineral fibers [155].

Very recent experiments from one of us (SK), carried out with cell lines and with lung tumor tissues (not mesotheliomas) of patients who had been either exposed or unexposed to asbestos fibers, indicated a couple of asbestos associated chromosomal areas. These findings are described in detail in Chapter 24. Even though chromosomal aberrations in MM are complex, they are not random and they are clonal in nature originating from one cell. Chapter 24 describes, in more details, these recurrent aberrations and their clinical significance.

The chromosomal alterations characteristic of MM, such as hypodiploid chromosomes number as well as deletions and losses in chromosome 14 and 10, are not seen in lung adenocarcinoma, which helps in differential diagnosis of these malignancies [179,180]. Interestingly, chromosomal 
aberrations in gastrointestinal stromal tumors (GIST) resemble those seen in MM [181]. To our knowledge GIST is not, however, an asbestos related tumor, but the similarities of chromosomal alterations may, instead, be related to similarities in mesenchymal stem cells from which the tumors originate.

To conclude, asbestos fibers cause a wide variety of chromosomal imbalances. Even though some of these changes may be recurrent, most of them are random. Various genetic changes caused by asbestos fibers offer a versatile genomic aberration reservoir, from which the aberrations promoting uncontrolled growth and malignant transformation are selected during the long initiation and progression (latency) period before tumor diagnosis. Variable chromosomal aberrations together with multifocal clonal evolution are consistent with this mechanism.

iii. Role of epigenetic alterations in the neoplastic transformation of $\underline{\text { mesothelial cells }}$

Altered gene expression in MPM could also be due to epigenetic mechanisms. MPM show specific patterns of gene methylation as compared to normal pleura or other tumors $[130,145,148,182,183]$. Data on methylation profiles of MPM will be described in detail chapter 24. Several studies suggested that DNA methylation at specific gene loci could be correlated with asbestos exposure. Significant associations between asbestos exposure and DNA methylation were first described in genes encoding heavy metal binding proteins, $M T 1 A$ and $M T A 2$, with a positive association for $M T 1 A$, but not for $M T 2 A$. Asbestos exposure does not seem to be an 
661

662

663

664

665

666

667

668

669

670

671

672

673

674

675

676

677

678

679

680

681

682

683

684 independent variable in this study [184]. A trend towards an increasing number of methylated cell cycle control genes (APC, CCND2, CDKN2A, $C D K N 2 B, H P P B P 1$ and $R A S S F 1)$ and increasing asbestos body counts was observed [144]. These findings were confirmed in a more recent, highthroughput methylation analysis underlining distinct methylation profiles between MPM from asbestos-exposed and unexposed patients, and a significant positive association between asbestos fiber burden and methylation status of CDKN2A, CDKN2B, RASSF1 and MT1A and about one hundred other loci [130].

MiRNAs are small (around 22 base pairs in size) RNAs that have a crucial role in posttranscriptional gene regulation. Their biosynthesis and functions have been described in more detail in Chapter 24. It has been demonstrated that MPM has a characteristic miRNA profile and that different MPM histopathological subtypes can be discriminated according to their profiles (see Chapter 24). Even though significantly differentially expressed miRNAs discriminated MPM patients according to smoking habit, this did not significantly discriminate asbestos-exposed patients versus unexposed [150]. The reason for this may be the low number of non-smoking patients. On the other hand, it is possible that patients classified into the unexposed category were actually exposed to asbestos fibers. Recent results provide evidence that a group of miRNAs differentiates asbestos associated lung adenocarcinomas from the non-associated tumors [185]. The results of these lung carcinoma studies are presented in detail in Chapter 24. As the mechanisms of the miRNA regulation are yet poorly understood, it is 
premature to speculate how asbestos fibers cause miRNA dysregulation seen in $\mathrm{MM}$ and in lung carcinomas. Nevertheless, some of them could be lost, as their loci are located in chromosomal regions frequently altered in MPM and possibly linked to asbestos exposure, as was demonstrated for miR31 which is close to the $C D K N 2 A$ locus [186]. So far, no experiments using cell cultures or experimental animals have been published that investigate miRNA profiles in asbestos-exposed cells or animals. Further investigations are needed to elucidate the mechanisms responsible for miRNA dysregulation and function in MM. In two MPM cell lines lacking either miR31 or miR29C, overexpression by transfection of these miRNAs decreased proliferation, migration, invasion, and colony formation $[186,187]$.

The molecular mechanisms responsible for epigenetic changes in MPM are poorly understood and it is not known whether they are directly induced by asbestos or they are indirect effects. Nevertheless, as with chromosomal imbalances, they most likely play a role in mesothelial carcinogenesis. in MPM by the occurrence of mutations and/or deregulated expression of specific regulators in comparison with normal mesothelial cells. These studies have been carried out in primary tumor samples but also in malignant mesothelial cell cultures developed from tissue samples. Pathway activation in MM has been shown by gene expression profiling. So far, the relationship 
investigated in MM. The effects of asbestos on mesothelial cells are discussed in paragraph 22-2.b.ii.

The Hippo pathway is of special interest regarding the high frequency of mutations detected in merlin encoded by the NF2 gene. Merlin negatively regulates cell proliferation. Its activity is affected by interaction between extracellular signals and membrane proteins, and activated merlin transduces signals suppressing the transcriptional activity of YAP coactivator [141]. In a recent study, another negative regulator of the hippo pathway, LATS2, was found to be deleted in 3 out of $6 \mathrm{MM}$ cell lines and in 1 out of 25 tumors by DNA sequencing analyses [188]. Merlin exists in two forms, active unphosphorylated or inactive phosphorylated. This later form is found in MPM cells possibly accounting for another mechanism for deregulation of the hippo pathway in these cells [189].

Cell cycle. Alteration of CDK inhibitor genes located at the INK4 (CDKN2A and $C D K N 2 B$ ) locus, as mentioned above, contributes to uncontrolled cell proliferation. However, cell cycle control can be affected in MM cells not only by the loss of other negative regulators, but also by the overexpression of cyclin-dependent kinases (CDKs), cyclins (CCNs), and regulators of the mitotic checkpoints. These alterations have been shown by gene profiling analyses using microarrays [190-192]. Overexpressed genes were involved in the regulation of all phases of the cell cycle, cell replication and control of cell cycle progression: cyclin-dependent kinase 1 (CDK1/CDC2); cell division cycle 6 (CDC6), a regulator of replication; cyclin-dependent kinase inhibitor 2C, p18, $(C D K N 2 C)$; cyclin $\mathrm{H}(C C N H)$; cyclin B1 (CCNB1), 

transcription factor $(F O X M 1)$, a regulator of gene expression in the $\mathrm{G} 2$ phase. Others are more specific of a response to DNA damage such as checkpoint kinase 1 (CHEK1). The protein encoded by this gene, Chk1, is required for checkpoint-mediated cell cycle arrest in response to DNA damage. Underexpression of cyclin D2 (CCND2), a regulator of Cdk4 and Cdk6, which controls the cell cycle at the G1/S transition), was also detected [190].

Several genes involved in the control of entry in mitosis and mitosis progression were also detected. Overexpression of aurora kinases has been reported in several studies [191,193]. Stathmin, a gene involved in the regulation of the microtubule dynamics, by inhibiting the formation of microtubules and/or promoting their depolymerisation, was strongly overexpressed in MPM, resulting in protein overexpression [194,195].

These results can account for the complex, even chaotic chromosomal alterations mentioned above, as a result of defective control of cell cycle progression through different phases of the cell cycle, including dysregulation of mitosis. proliferation and differentiation, survival, apoptosis and Wnt signaling [196]. In normal cells, the MAPK pathway is triggered by the activating phosphorylation of tyrosine kinase receptors (RTKs), followed by a protein kinase cascade. Downstream networks from RTKs can be activated by RTK 
The MAPK signaling pathway is constitutively activated in MM as demonstrated by the phosphorylation and activation of downstream proteins of the MAPK cascade, extracellular-regulated kinases (ERKs), Jun aminoterminal kinases/stress-activated kinases (JNKs/SAPKs), and p38 MAPK $[197,198]$ and inhibition of cell proliferation and induction of apoptosis by inhibitors of the pathway [199]. RTKs activation can be achieved by a variety of growth factors, EGF family, PDGF, FGF, HGF/SF and cytokines such as TGF- $\beta$, TNF and IL1. In a recent study, the relative levels of tyrosine phosphorylation of 42 distinct RTKs was determined in MM cell lines established from surgical specimens. Coordinated activation of several RTKs: EGFR, ERBB3, AXL and MET was found [200].

MPM cells express both vascular endothelial growth factor (VEGF) and the VEGF receptors (fms-related tyrosine kinases, FLT1 and FLT4, and fetal liver kinase, $K D R / F L K 1$ ) [201-204]. VEGF expression was enhanced in a large proportion of MPM in comparison with nonneoplastic specimens [205]. An autocrine role for VEGF in cell proliferation has been suggested $[203,206]$.

MM cell growth may also be linked to autocrine or paracrine stimulation by platelet-derived growth factor (PDGF), and the regulation by PDGF appears to be complex in MM cells. PDGF has been suggested as a regulatory factor for proliferation of $\mathrm{MM}$ cells, either directly or indirectly via the hyaluronan/CD44 pathway [207,208]. Human MM cells express high levels of PDGF-A, and PDGF-B and PDGFR-B while normal human mesothelial cells express low levels of PDGF-A mRNA chain and PDGFR-A [209,210]. 
PDGF-A could contribute to tumor formation via a paracrine mechanism $[211,212]$.

Epidermal growth factor receptor (EGFR) is over-expressed in 44-97\% of MM as found by immunohistochemical studies, but no mutation was detected in contrast with others types of cancer [213].

Human MM cells express insulin growth factor (IGF) and insulin growth factor receptors (IGFR), and the activation of IGFR activates downstream signaling [214,215]. IGF-I appears to function as an autocrine growth factor in human mesothelial cells [216]. IGFBPs also regulate IGF-dependent growth $[215,217,218]$.

Hepatocyte growth factor receptor (MET) is a proto-oncogene. It is the receptor for the ligand hepatocyte growth factor/scattering factor (HGF/SF). Mutation in the MET gene has been detected in a few MM cell lines $[219,220]$. Both MET and HGF/SF proteins are expressed in some MPM $[221,222]$. In vitro HGF/SF increases spreading, motility and/or invasiveness of mesothelial cell lines and inhibition of MET reduced cell proliferation $[219,223,224]$. The activation status of MET and other RTKs, EGFR family (Erb1, Erb2, Erb3), PDGF-A and PDGFR-B has been investigated in 20 MPM cell lines and 23 primary specimens of MPM, and the effect of METspecific inhibitors (MET-shRNA interference vector and RTK inhibitors) was investigated on cell lines [220]. The results showed that inhibition of a 802 single RTK was not sufficient to obtain a tumor suppressor effect but that inhibition of multiple RTK was required [220]. 
Activation of RTKs also induces activation of other downstream signaling cascades including phosphatidylinositol-3-kinase (PI3K-AKT) pathway, regulating cell survival and proliferation, cell migration and apoptosis. Phosphorylation of AKT protein, the active form of the protein, and activation of the Akt pathway have been demonstrated in MM cells [225,226]. In PTEN, a TSG and negative regulator of the PI3K-AKT pathway, homozygous deletion has been reported in a small subset of MPM cell lines $[227,228]$.

The Wnt signaling pathway regulates developmental processes, cell proliferation, and cell polarity and its activation prevents beta-catenin inactivation, a coactivator of transcription, allowing the expression of a variety of genes exerting pleiotropic effects [229]. However, cell growth inhibition and apoptosis of MPM cells was observed according to a betacatenin-independent inhibition of Wnt signaling [230,231]. In MPM, the Wnt pathway could be altered as a result of promoter hypermethylation of regulatory genes [230,232,233]. Gene expression profiling of MM cell lines, primary MPM tumors and normal pleural tissue demonstrated that numerous Wnt and Wnt-related genes were upregulated and that some WNT antagonists were downregulated [234]. These results suggest that deregulation of the Wnt signaling pathway is involved in mesothelial carcinogenesis. in dysfunction of apoptosis in MPM. Moreover specific regulators can 

methylation of cell death agonist TRAIL receptors and/or by the low levels or activity of antiapoptotic proteins (Bcl-2, Bcl-xL and Mcl-1) regulating mitochondrial function [226,235-238].

\section{Concluding remarks}

Several hallmarks of cancer have been considered to contribute to neoplastic transformation [239]. These include direct molecular damage induced by carcinogens that alter the genome and induce dysregulated cellular functions and resistance to apoptosis. Neoplastic progression is associated with genetic and chromosomal instability. Genetic instability reflects unrepaired DNA damage which may arise either from increased rates of damage or defective mechanisms responsible for genetic integrity. Chromosomal instability arises from dysregulation of mitotic checkpoints. As a consequence, cancer cells fail to control the cell cycle and to correct error-free DNA and to repair chromosome damage. Investigation of the mechanism of asbestos carcinogenicity has focused on interactions between asbestos and target cells, especially mesothelial cells, and early responses of lung and pleural cells to asbestos exposure. Studies of human MM cells provide the opportunity to identify the cellular and molecular changes that have beginning of asbestos exposure. However, the body of data obtained by these mechanistic studies using cells and experimental animals reveal that all types 
852

853

854

855

856

857

858

859

860

861

862

863

864

865

866

867

868

869

870

871

872

873

874

875 of asbestos fibers induce early genetic changes directly and also indirectly due to the early recruitment of macrophages and inflammatory cells. These early genetic changes cause molecular alterations that perturb cell cycle control giving rise to sustained cell proliferation, and additional genetic and chromosomal instability. Early activation of proliferation and survival pathways has been shown in asbestos-exposed mesothelial cells in culture in short-term experiments. The relationship between these early effects and the characteristics of $\mathrm{MM}$ cells studied 30 to 40 years after the beginning of exposure remains to be explored.

When the molecular status of human MM is placed in the context of results from studies with cells in culture and in animals, consistent mechanisms emerge. Among genes inactivated in MM, those at the INK4 locus control the cell cycle, and loss of their function results in failure of cell cycle control. The functional consequences of P14/ARF loss are more complex. This does not seem to be associated with p53 degradation, as expected from the known negative regulation of p53 stability by $\mathrm{p} 14^{\mathrm{ARF}}$ loss. In contrast, p53 appears to be stabilized in MM, suggesting basal overexpression and/or another type of dysregulation. The p53 protein is constitutively expressed, not only in MM cells in culture, but also in immunohistological sections of primary tumors [240-243]. Candidates for p53 activation could be up regulation of IGF-1/AKT/mTOR pathway and altered energy metabolism, which have been identified as additional functions of $\mathrm{p} 53$, as recently reviewed [244]. The AKT/mTOR cell survival and growth pathway is activated in $\mathrm{MM}$ and linked to apoptosis resistance. It is remarkable that 
current approaches to control MM proliferation have focused on the resistance of MM cells to apoptosis [245,246]. Energy metabolism of MM cells is characterized as aerobic glycolysis (the Warburg effect), and the p53 protein could be induced to shut down this pathway [244,247]. The low rate of p53 mutations found in asbestos-induced MM in both humans and mice and the functional response of p53 in asbestos-exposed cells are consistent with these observations.

Transcriptional analyses suggest that cell cycle checkpoints are compromised in MM. Differential expression of genes encoding proteins involved in the control of mitosis, AURKA, AURKB and CHEK1 has been reported in comparison with normal mesothelium or normal mesothelial cells. Aurora B (encoded by $A U R K B$ ) is localized in the internal part of kinetochore, and is the enzymatic component of the "chromosome passenger complex", which also includes the internal protein of the centromere, and is involved in mitotic spindle organization, chromosome segregation, and cytokinesis [248]. Those events are compromised in cells that have internalized asbestos fibers as demonstrated using different target cells, including mesothelial cells [249-251] (see in paragraph 22-2.b.ii). In their review, Lampson and Cheeseman [248] suggest Aurora B activity to be modulated by tension forces. Chromosome segregation is controlled at several levels and chromosome movement is driven by motors that are linked to kinetochore associated microtubules and the centrosome. Tensile strengths are developed during this process. So far, mechanical properties of carcinogenic fibers have not been taken into consideration, but it would be of 
interest to consider this parameter in the context of fiber interactions with the mitotic apparatus during cell division. Tensile strengths induce tissue and cell deformation. In a recent study carried out with nanoparticles, Mijailovich et al. [252] investigated the mechanisms by which deposited particles exert mechanical forces and provoke the particle indentation into alveolar tissue. They found that these mechanisms are centred on a mechanical balance between surface tension forces and tissue elastic forces. These concepts should be considered to account for the effects of fibers on cells and tissues, especially during cytosqueleton remodeling and mitosis progression.

Alteration of NF2 is also consistent with a physical mechanism of action of asbestos fibers with mesothelial cells. The encoded protein, merlin is a regulator involved in signaling pathways that control, among other parameters, cell shape, proliferation (involving the hyaluronic acid receptor, CD44, which is important for proliferation of MM cells), survival, and motility [160]. Merlin is a component of the adherens junctions and other types of cell-to-cell contacts $[158,159]$. As cell division is mechanically impaired by the presence of asbestos fibers, mutation of NF2 could be responsible for enhanced proliferation as well as impaired mitotic control. The overall consequences of these effects would be genetic and chromosomal instability and possibly, evasion from apoptosis. It would be important to investigate the repair processes induced by exposure to asbestos, and whether these processes are impaired, leading to additional 

cells. An activated oncogene has not clearly been identified yet. From studies carried out in genetically modified mice, it seems that NF2 could facilitate tumor progression, but Nf2 deficiency does not act as an initiator, as the latent period for development of $\mathrm{MM}$ is similar in WT and heterozygous $\mathrm{Nf} 2^{+/-}$crocidolite-exposed mice [23]. In "spontaneous" MM

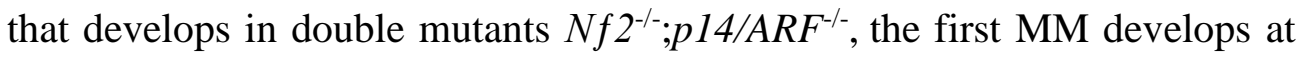
cell transformation [53]. Further studies will improve our knowledge of the nature and relative role of gene alterations in MM. mesothelial cell and asbestos fibers towards a fibrotic or a neoplastic pathway are dependent on several parameters as discussed above. Other 


\section{$9445 \quad$ References}

945 1. Lippmann M, Yeates DB, Albert RE. Deposition, retention and clearance of inhaled 946 particles. Br J Industr Med.1980;37:337-362.

947 2. Oberdorster G. Evaluation and use of animal models to assess mechanisms of fibre 948 carcinogenicity. IARC Sci Publ.1996:107-125.

949 3. Miserocchi GA, Sancini GA, Mantegazza F, Chiappino G. Translocation pathways for $950 \quad$ inhaled asbestos fibers. Environ Health.2008;7:4.

951 4. Donaldson K, Murphy FA, Duffin R, Poland CA. Asbestos, carbon nanotubes and the 952 pleural mesothelium: a review and the hypothesis regarding the role of long fibre retention in the parietal pleura, inflammation and mesothelioma. Part Fibre

955 5. Wang NS. Anatomy of the pleura. Clin Chest Med.1998;19:229-240.

956 6. Wang NS. The preformed stomas connecting the pleural cavity and the lymphatics in the 957 parietal pleura. Am Rev Respir Dis.1975;111:12-20.

958 7. Hammar SP. The pathology of benign and malignant pleural disease. Chest Surg Clin N $959 \quad$ Am.1994;4:405-430.

960 8. Holt PF. Transport of inhaled dust to extrapulmonary sites. J Pathol.1981;133:123-129.

9619 9uller KM, Schmitz I, Konstantinidis K. Black spots of the parietal pleura: morphology 962 and formal pathogenesis. Respiration.2002;69:261-267.

963 10. Mitchev K, Dumortier P, De Vuyst P. 'Black Spots' and hyaline pleural plaques on the 964 parietal pleura of 150 urban necropsy cases. Am J Surg Pathol.2002;26:1198-1206.

965 11. Pooley FD. Proceedings: The recognition of various types of asbestos as minerals, and in 966 tissues. Clin Sci Mol Med.1974;47:11P-12P.

967 12. Dodson RF, O'Sullivan MF, Huang J, Holiday DB, Hammar SP. Asbestos in 968 extrapulmonary sites: omentum and mesentery. Chest.2000;117:486-493.

969 13. Boffetta P. Epidemiology of peritoneal mesothelioma: a review. Ann Oncol.2007;18:985$970 \quad 990$.

971 14. Price B, Ware A. Time trend of mesothelioma incidence in the United States and 972 projection of future cases: An update based on SEER data for 1973 through 2005. Crit Rev Toxicol.2009;39:576-588. 
974 15. Albin M, Magnani C, Krstev S, Rapiti E, Shefer I. Asbestos and cancer: An overview of 975 current trends in Europe. Environ Health Perspect.1999;107 Suppl 2:289-298.

976 16. Kishimoto T, Ozaki S, Kato K, Nishi H, Genba K. Malignant pleural mesothelioma in parts of Japan in relationship to asbestos exposure. Ind Health.2004;42:435-439.

978 17. Goldberg M, Imbernon E, Rolland P, et al;. The French National Mesothelioma Surveillance Program. Occup Environ Med.2006;63:390-395.

980 18. Park EK, Hannaford-Turner KM, Hyland RA, Johnson AR, Yates DH. Asbestos-related occupational lung diseases in NSW, Australia and potential exposure of the general population. Ind Health.2008;46:535-540.

19. Bernstein D, Castranova V, Donaldson K, et al;. Testing of fibrous particles: short-term assays and strategies. of an ILSI Risk Science Institute Working Group Inhal Toxicol.2005;17:497-537.

986 20. Wagner JC, Berry G. Mesotheliomas in rats following inoculation with asbestos. British Journal of Cancer.1969;23:567-581.

988 21. Davis JM. Structural variations between pleural and peritoneal mesotheliomas produced in rats by the injection of crocidolite asbestos. Ann Anat Pathol (Paris).1976;21:199-210.

990 22. Davis JM. The histopathology and ultrastructure of pleural mesotheliomas produced in the rat by injections of crocidolite asbestos. Br J Exp Pathol.1979;60:642-652.

24. Adamson IYR, Bakowska J. KGF and HGF are growth factors for mesothelial cells in pleural lavage fluid after intratracheal asbestos. Exp Lung Res.2001;27:605-616.

997 25. Gelzleichter TR, Bermudez E, Mangum JB, Wong BA, Moss OR, Everitt JI. Pulmonary and pleural responses in Fischer 344 rats following short-term inhalation of a synthetic vitreous fiber .2. Pathobiologic responses. Fund Appl Toxicol.1996;30:39-46.

1000 26. Everitt JI, Gelzleichter TR, Bermudez E, et al;. Comparison of pleural responses of rats and hamsters to subchronic inhalation of refractory ceramic fibers. Environ Health Perspect.1997;105 Suppl 5:1209-1213. 
1003 27. Boutin C, Dumortier P, Rey F, Viallat JR, Devuyst P. Black spots concentrate oncogenic asbestos fibers in the parietal pleura: thoracoscopic and mineralogic study. Amer J Respir Crit Care Med.1996;153:444-449.

28. Jaurand MC. Use of in-vitro genotoxicity and cell transformation assays to evaluate potential carcinogenicity of fibres. In: Kane AB, Boffetta P, Sarracci R, Wilbourn JD,

29. Huang SXL, Jaurand MC, Kamp DW, Whysner J, Hei T. Role of mutagenicity in asbestos fiber-induced carcinogenicity and other diseases. Journal of Toxicology and Environmental Health, Part B.2011;14:1-67.

31. Ruosaari ST, Nymark PE, Aavikko MM, et al;. Aberrations of chromosome 19 in asbestos-associated lung cancer and in asbestos-induced micronuclei of bronchial epithelial cells in vitro. Carcinogenesis.2008;29:913-917.

1017 32. Zanella CL, Posada J, Tritton TR, Mossman BT. Asbestos causes stimulation of the extracellular signal-regulated kinase 1 mitogen-activated protein kinase cascade after phosophorylation of the epidermal growth factor receptor. Cancer Res.1996;56:53345338.

33. Faux SP, Houghton CE, Hubbard A, Patrick G. Increased expression of epidermal growth factor receptor in rat pleural mesothelial cells correlates with carcinogenicity of mineral fibres. Carcinogenesis.2001;12:2275-2280.

34. Levresse V, Renier A, Fleury-Feith J, et al;. Analysis of cell cycle disruptions in cultures of rat pleural mesothelial cells exposed to asbestos fibres. Amer J Respir Cell Mol Biol.1997; 17:660-671.

36. Levresse V, Renier A, Levy F, Broaddus VC, Jaurand MC. DNA breakage in asbestos1031 treated normal and transformed (TSV40) rat pleural mesothelial cells. Mutagenesis.2000;15:239-244. 
1033 37. Liu W, Ernst JD, Broaddus VC. Phagocytosis of crocidolite asbestos induces oxidative 1034 stress, DNA damage, and apoptosis in mesothelial cells. Am J Respir cell Mol Biol.2000;23:371-378.

1036 38. Puhakka A, Ollikainen T, Soini Y, et al;. Modulation of DNA single-strand breaks by intracellular glutathione in human lung cells exposed to asbestos fibers. Mutat Res.2002;514:7-17.

1039

39. Pietruska JR, Kane AB. SV40 oncoproteins enhance asbestos-induced DNA doublestrand breaks and abrogate senescence in murine mesothelial cells. Cancer Res.2007;67:3637-3645.

1042 40. Dong HY, Buard A, Renier A, Levy F, Saint-Etienne L, Jaurand MC. Role of oxygen derivatives in the cytotoxicity and DNA damage produced by asbestos on rat pleural mesothelial cells in vitro. Carcinogenesis.1994;15:1251-1255.

1045

41. Dong HY, Buard A, Levy F, Renier A, Laval F, Jaurand MC. Synthesis of poly(ADPribose) in asbestos treated rat pleural mesothelial cells in culture. Mutat Res.1995;331:197-204.

42. Achard S, Perderiset M, Jaurand MC. Sister chromatid exchanges in rat pleural mesothelial cells treated with crocidolite, attapulgite or benzo 3-4 pyrene. $\mathrm{Br} \mathrm{J}$ Ind Med.1987;44:281-283.

1051

43. Wang NS, Jaurand MC, Magne L, Kheuang L, Pinchon MC, Bignon J. The interactions

1052

1053

1054 between asbestos fibers and metaphase chromosomes of rat pleural mesothelial cells in culture. A scanning and transmission electron microscopic study. Am J Pathol.1987;126:343-349.

1055 44. Yegles M, Saint-Etienne L, Renier A, Janson X, Jaurand MC. Induction of metaphase and 1056

45. Pelin K, Kivipensas P, Linnainmaa K. Effects of asbestos and man-made vitreous fibers on cell division in cultured human mesothelial cells in comparison to rodent cells. Environ Mol Mutag.1995;25:118-125.

1061 46. Pelin K, Hirvonen A, Taavitsainen M, Linanainmaa K. Cytogenetic response to asbestos 1062 fibers in cultured human primary mesothelial cells from 10 different donors. Mutat Res.1995;334:225-233. 
Chapter ex15 new22Revised Vf(text and tables).doc

page $45 / 72$

1064 47. Yegles M, Janson X, Dong HY, Renier A, Jaurand MC. Role of fibre characteristics on cytotoxicity and induction of anaphase/telophase aberrations in rat pleural mesothelial cells in vitro. Correlations with in vivo animal findings. Carcinogenesis.1995;16:27512758 .

1068 48. Poser I, Rahman Q, Lohani M, et al;. Modulation of genotoxic effects in asbestos-exposed primary human mesothelial cells by radical scavengers, metal chelators and a glutathione precursor. Mutat Res.2004;559:19-27.

1071

49. Broaddus VC. Asbestos, the mesothelial cell and malignancy: a matter of life or death.

1072 Am J Respir Cell Mol Biol.1997;17:657-659.

1073 50. Marsella JM, Liu BL, Vaslet CA, Kane AB. Susceptibility of p53-deficient mice to induction of mesothelioma by crocidolite asbestos fibers. Environ Health paerspect.1997;105(supp 5):1069-1072.

1076

51. Altomare DA, Vaslet CA, Skele KL, et al;. A mouse model recapitulating molecular features of human mesothelioma. Cancer Res.2005;65:8090-8095.

1078 52. Lecomte C, Andujar P, Renier A, et al;. Similar tumor suppressor gene alteration profiles in asbestos-induced murine and human mesothelioma. Cell Cycle.2005;4:1862-1869.

1080 53. Jongsma J, van Montfort E, Vooijs M, et al;. A conditional mouse model for malignant mesothelioma. Cancer Cell.2008;13:261-271.

1082

54. Merchant JA. Human epidemiology: a review of fiber type and characteristics in the

1083 development of malignant and nonmalignant disease. Environ Health Perspect.1990;88:287-293.

55. Baris YI, Grandjean P. Prospective study of mesothelioma mortality in Turkish villages with exposure to fibrous zeolite. J Natl Cancer Inst.2006;98:414-417.

1087 56. Coin PG, Roggli VL, Brody AR. Persistence of long, thin chrysotile asbestos fibers in the 1088 lungs of rats. Environ Health Perspect.1994;102 Suppl 5:197-199.

1089 57. Greillier L, Astoul P. Mesothelioma and asbestos-related pleural diseases. $1090 \quad$ Respiration.2008;76:1-15.

1091 58. IOM. Asbestos: Selected Cancers. Washington, D.C.: The National Academies Press; 1092 2006.

1093 59. Fubini B. Surface reactivity in the pathogenic response to particulates. Environ health Perspect.1997;105:1013-1020. 
Chapter ex15 new22Revised Vf(text and tables).doc

page $46 / 72$

1095 60. McDonald JC. Epidemiology of malignant mesothelioma--an outline. Ann Occup $1096 \quad$ Hyg.2010;54:851-857.

1097 61. McDonald JC, Harris J, Armstrong B. Mortality in a cohort of vermiculite miners exposed

1098

1099

1100

62. IARC. Silica and some silicates. In: IARC Press G, ed. Monographs on the evaluation of carcinogenic risk of chemical to humans. Vol vol. 421987:39-143.

1102

1103

1104

64. Dostert C, Petrilli V, Van Bruggen R, Steele C, Mossman BT, Tschopp J. Innate immune activation through Nalp3 inflammasome sensing of asbestos and silica. Science.2008;320:674-677.

65. Poland CA, Duffin R, Kinloch I, et al;. Carbon nanotubes introduced into the abdominal cavity of mice show asbestos-like pathogenicity in a pilot study. Nat Nanotechnol.2008;3:423-428.

66. Mercer RR, Scabilloni J, Wang L, et al;. Alteration of deposition pattern and pulmonary response as a result of improved dispersion of aspirated single-walled carbon nanotubes in a mouse model. Am J Physiol Lung Cell Mol Physiol.2008;294:L87-97.

68. Porter DW, Hubbs AF, Mercer RR, et al;. Mouse pulmonary dose- and time courseresponses induced by exposure to multi-walled carbon nanotubes. Toxicology.2010;269:136-147.

69. Mercer RR, Hubbs AF, Scabilloni JF, et al;. Distribution and persistence of pleural penetrations by multi-walled carbon nanotubes. Part Fibre Toxicol.2010;7:28.

1121 70. Takagi A, Hirose A, Nishimura T, et al;. Induction of mesothelioma in p53+/- mouse by intraperitoneal application of multi-wall carbon nanotube. J Toxicol Sci.2008;33:105-116.

1123 71. Sakamoto Y, Nakae D, Fukumori N, et al;. Induction of mesothelioma by a single intrascrotal administration of multi-wall carbon nanotube in intact male Fischer 344 rats. J Toxicol Sci.2009;34:65-76. 
Chapter ex15 new22Revised Vf(text and tables).doc

page $47 / 72$

1126 72. Muller J, Delos M, Panin N, Rabolli V, Huaux F, Lison D. Absence of carcinogenic response to multiwall carbon nanotubes in a 2-year bioassay in the peritoneal cavity of the rat. Toxicol Sci.2009;110:442-448.

1129 73. Fubini B, Otero-Arean C. Clinical aspects of the toxicity of inhaled mineral dusts. Chem $1130 \quad$ Soc Rev.1999;28:373-381.

1131 74. Fubini B, Mollo L. Role of iron in the reactivity of mineral fibers. Toxicol Lett.1995;82$1132 \quad 3: 951-960$.

1133 75. Hardy JA, Aust AE. The effect of iron binding on the ability of crocidolite asbestos to catalyze DNA single-strand breaks. Carcinogenesis.1995;16:319-325.

1135 76. Shukla A, Ramos-Nino M, Mossman B. Cell signaling and transcription factor activation 1136 by asbestos in lung injury and disease. Intl J Biochem Cell Biol.2003;35:1198-1209.

1137 77. Upadhyay D, Kamp DW. Asbestos-induced pulmonary toxicity: role of DNA damage and apoptosis. Exp Biol Med (Maywood).2003;228:650-659.

80. Fenoglio I, Tomatis M, Lison D, et al;. Reactivity of carbon nanotubes: free radical

81. Galano A, Francisco-Marquez M, Martinex A. Influence of point defects on the freeradical scavenging capability of single-walled carbon nanotubes. J. Phys. Chem. C $2010 ; 114$.

1150 82. Di Sotto A, Chiaretti M, Carru GA, Bellucci S, Mazzanti G. Multi-walled carbon nanotubes: Lack of mutagenic activity in the bacterial reverse mutation assay. Toxicol Lett.2009;184:192-197.

1153 83. Wirnitzer U, Herbold B, Voetz M, Ragot J. Studies on the in vitro genotoxicity of baytubes((R)), agglomerates of engineered multi-walled carbon-nanotubes (MWCNT). 
Chapter ex15 new22Revised Vf(text and tables).doc

page $48 / 72$

1156 84. Yamashita K, Yoshioka Y, Higashisaka K, et al;. Carbon nanotubes elicit DNA damage and inflammatory response relative to their size and shape. Inflammation.2010;33:276280.

1159 85. Muller J, Decordier I, Hoet PH, et al;. Clastogenic and aneugenic effects of multi-wall carbon nanotubes in epithelial cells. Carcinogenesis.2008;29:427-433.

86. Kisin ER, Murray AR, Sargent L, et al;. Genotoxicity of carbon nanofibers: are they potentially more or less dangerous than carbon nanotubes or asbestos? Toxicol Appl Pharmacol.2011;252:1-10.

87. Lindberg HK, Falck GC, Suhonen S, et al;. Genotoxicity of nanomaterials: DNA damage and micronuclei induced by carbon nanotubes and graphite nanofibres in human bronchial epithelial cells in vitro. Toxicol Lett.2009;186:166-173.

1167 88. Pacurari M, Yin XJ, Ding M, et al;. Oxidative and molecular interactions of multi-wall carbon nanotubes (MWCNT) in normal and malignant human mesothelial cell. Nanotoxicol.2008;2:155-170

89. Pacurari M, Yin XJ, Zhao J, et al; Raw single-wall carbon nanotubes induce oxidative stress and activate MAPKs, AP-1, NF-kappaB, and Akt in normal and malignant human mesothelial cells. Environ Health Perspect.2008;116:1211-1217.

91. Manning CB, Vallyathan V, Mossman BT. Diseases caused by asbestos: mechanisms of injury and disease development. Int Immunopharmacol.2002;2:191-200.

1179 92. Park SH, Aust A. Participation of iron and nitric oxide in the mutagenicity of asbestos in hgprt-, gpt+ chines hamster V79 cells. Cancer Res.1998;58:1144-1148.

1181 93. Hei T, Louie D, Zhao YL. Genotoxicity versus carcinogenicity: Implications from fiber toxicity studies. Inhal Toxicol.2000;12:141-147.

94. MacCorkle RA, Slattery SD, Nash DR, Brinkley BR. Intracellular protein binding to asbestos induces aneuploidy in human lung fibroblasts. Cell Motil Cytoskeleton.2006;63:646-657. 
95. Sargent LM, Reynolds SH, Castranova V. Potential pulmonary effects of engineered carbon nanotubes: in vitro genotoxic effects. Nanotoxicology.2010;4:396-408.

96. Berman DW, Crump KS. A meta-analysis of asbestos-related cancer risk that addresses fiber size and mineral type. Crit Rev Toxicol.2008;38 Suppl 1:49-73.

1190 97. Suzuki Y, Yuen SR, Ashley R. Short, thin asbestos fibers contribute to the development of human malignant mesothelioma: pathological evidence. Int $\mathrm{J}$ Hyg Environ Health.2005;208:201-210.

98. Dodson RF, Hammar SP. Pleural mesothelioma in a woman whose documented past exposure to asbestos was from smoking asbestos-containing filtered cigarettes: the comparative value of analytical transmission electron microscopic analysis of lung and lymph-node tissue. Inhal Toxicol.2006;18:679-684.

99. Hesterberg TW, Chase G, Axten C, et al;. Biopersistence of synthetic vitreous fibers and amosite asbestos in the rat lung following inhalation. Toxicol Appl Pharmacol.1998;151:262-275.

100. Miller BG, Searl A, Davis JMG, et al;. Influence of fibre length, dissolution and 1201

101. Akiyama I, Ogami A, Oyabu T, Yamato H, Morimoto Y, Tanaka I. Pulmonary effects and 1204 biopersistence on the production of mesothelioma in the rat peritoneal cavity. Ann occup Hyg.1999;43:155-166.

1212 104. Mast RW, Yu CP, Oberdorster G, McConnell EE, Utell MJ. A retrospective review of the biopersistence of deposited silicon carbide whisker after 1-year inhalation in rats. Inhal Toxicol.2007;19:141-147.

102. Johnson NF, Hahn FF. Induction of mesothelioma after intrapleural inoculation of F344 rats with silicon carbide whiskers or continuous ceramic filaments. Occup Environ Med.1996;53:813-816.

103. Rodelsperger K, Bruckel B. The carcinogenicity of WHO fibers of silicon carbide: SiC whiskers compared to cleavage fragments of granular SiC. Inhal Toxicol.2006;18:623631. carcinogenicity of refractory ceramic fiber in two chronic fischer 344 rat inhalation studies: an assessment of the MTD and implications for risk assessment. Inhal Toxicol.2000;12:1141-1172. 
1216 105. Wagner JC, Skidmore JW, Hill RJ, Griffiths DM. Erionite exposure and mesotheliomas in 1217 rats. British Journal of Cancer.1985;51.

1218 106. Johnson NF, Edwards RE, Munday DE, Rowe N, Wagner JC. Pluripotential nature of 1219 mesotheliomata induced by inhalation of erionite in rats. Br J Exp Pathol.1984;65:377$1220 \quad 388$.

1221 107. Kane AB. Animal models of malignant mesothelioma. Inhal Toxicol.2006;18:1001-1004.

1222 108. Saffiotti U. Meosthelioma carcinogenesis: In vivo models. In: Pass H, Vogelzang N, Carbone M, eds. Malignant mesothelioma. Vol 26: Springer; 2005:60-86.

1224 109. Liu X, Guo L, Morris D, Kane AB, Hurt RH. Targeted Removal of Bioavailable Metal as a Detoxification Strategy for Carbon Nanotubes. Carbon N Y.2008;46:489-500.

110. Allen BL, Kichambare PD, Gou P, et al;. Biodegradation of single-walled carbon nanotubes through enzymatic catalysis. Nano Lett.2008;8:3899-3903.

111. Liu X, Hurt RH, Kane AB. Biodurability of Single-Walled Carbon Nanotubes Depends on Surface Functionalization. Carbon N Y.2010;48:1961-1969.

1230 112. Nagai H, Toyokuni S. Biopersistent fiber-induced inflammation and carcinogenesis: lessons learned from asbestos toward safety of fibrous nanomaterials. Arch Biochem Biophys.2010;502:1-7.

1233 113. Donaldson K, Aitken R, Tran L, et al;. Carbon nanotubes: a review of their properties in relation to pulmonary toxicology and workplace safety. Toxicol Sci.2006;92:5-22.

1235 114. Pacurari M, Castranova V, Vallyathan V. Single- and multi-wall carbon nanotubes versus asbestos: are the carbon nanotubes a new health risk to humans? J Toxicol Environ Health

1238 115. Wick P, Manser P, Limbach LK, et al;. The degree and kind of agglomeration affect carbon nanotube cytotoxicity. Toxicol Lett.2007;168:121-131.

1240 116. Jaurand MC, Renier A, Daubriac J. Mesothelioma: Do asbestos and carbon nanotubes pose the same health risk? Part Fibre Toxicol.2009;6:16-29.

1242 117. Kane AB, Hurt RH. Nanotoxicology: the asbestos analogy revisited. Nat $1243 \quad$ Nanotechnol.2008;3:378-379.

1244 118. Aschberger K, Johnston HJ, Stone V, et al;. Review of carbon nanotubes toxicity and exposure--appraisal of human health risk assessment based on open literature. Crit Rev Toxicol.2010;40:759-790. 
119. Kinnula VL, Everitt JI, Mangum JB, Chang LY, Crapo JD. Antioxidant defense mechanisms in cultured pleural mesothelial cells. Am J Respir Cell Mol Biol.1992;7:95103.

120. Lechner JF, Tokiwa T, LaVeck M, et al;. Asbestos-associated chromosomal changes in human mesothelial cells. Proc Natl Acad Sci U S A.1985;82:3884-3888.

121. Hesterberg TW, Hart GA, Chevalier J, et al;. The importance of fiber biopersistence and lung dose in determining the chronic inhalation effects of X607, RCF1, and chrysotile asbestos in rats. Toxicol Appl Pharmacol.1998;153:68-82.

122. Kodama Y, Boreiko CJ, Maness SC, Hesterberg TW. Cytotoxic and cytogenetic effects of asbestos on human bronchial epithelial cells in culture. Carcinogenesis.1993;14:691-697.

123. Kamp DW, Israbian VA, Yeldandi AV, Panos RJ, Graceffa P, Weitzman SA. Phytic acid, an iron chelator, attenuates pulmonary inflammation and fibrosis in rats after intratracheal instillation of asbestos. Toxicol Pathol.1995;23:689-695.

124. Shukla A, Jung M, Stern M, et al;. Asbestos induces mitochondrial DNA damage and 1261 dysfunction linked to the development of apoptosis. Am J Physiol Lung Cell Mol Physiol.2003;285:L1018-1025.

1263 125. Srivastava RK, Lohani M, Pant AB, Rahman Q. Cyto-genotoxicity of amphibole asbestos fibers in cultured human lung epithelial cell line: role of surface iron. Toxicol Ind Health.2010;26:575-582.

126. Hei TK, He ZY, Suzuki K. Effects of antioxidants on fiber mutagenesis. Carcinogenesis.1995;16:1573-1578.

127. Kamp DW, Weitzman SA. The molecular basis of asbestos induced lung injury. Thorax.1999;54:638-652.

1270 128. Heintz NH, Janssen-Heininger YM, Mossman BT. Asbestos, lung cancers, and 1271

130. Christensen BC, Houseman EA, Godleski JJ, et al;. Epigenetic profiles distinguish pleural mesotheliomas: from molecular approaches to targeting tumor survival pathways. Am J Respir Cell Mol Biol.2010;42:133-139.

129. Murthy SS, Testa JR. Asbestos, chromosomal deletions, and tumor suppressor gene alterations in human malignant mesothelioma. J Cell Physiol.1999;180:150-157. mesothelioma from normal pleura and predict lung asbestos burden and clinical outcome. Cancer Res.2009;69:227-234. 
1278 131. Valinluck V, Sowers LC. Inflammation-mediated cytosine damage: a mechanistic link between inflammation and the epigenetic alterations in human cancers. Cancer Res.2007;67:5583-5586.

1281 132. Kasai H, Kawai K. DNA methylation at the C-5 position of cytosine by methyl radicals: a possible role for epigenetic change during carcinogenesis by environmental agents. Chem Res Toxicol.2009;22:984-989.

133. Reuter S, Gupta SC, Chaturvedi MM, Aggarwal BB. Oxidative stress, inflammation, and cancer: how are they linked? Free Radic Biol Med.2010;49:1603-1616.

134. Mutsaers SE. The mesothelial cell. Int J Biochem Cell Biol.2004;36:9-16.

135. Michailova KN, Usunoff KG. Serosal membranes (pleura, pericardium, peritoneum). Normal structure, development and experimental pathology. Adv Anat Embryol Cell Biol.2006;183:i-vii, 1-144, back cover.

136. Mutsaers SE, Whitaker D, Papadimitriou JM. Mesothelial regeneration is not dependent on subserosal cells. J Pathol.2000;190:86-92.

1292 137. Mutsaers SE. Mesothelial cells: their structure, function and role in serosal repair. Respirology.2002;7:171-191.

1294 138. Foley-Comer AJ, Herrick SE, Al-Mishlab T, Prele CM, Laurent GJ, Mutsaers SE. Evidence for incorporation of free-floating mesothelial cells as a mechanism of serosal healing. J Cell Sci.2002;115:1383-1389.

1297 139. Mor O, Yaron P, Huszar M, et al;. Absence of p53 mutations in malignant mesothelioma. Am J Respir Cell Mol Biol.1997;16:9-13.

140. Kitamura F, Araki S, Tanigawa T, Miura H, Akabane H, Iwasaki R. Assessment of mutations of $\mathrm{Ha}$ - and Ki-ras oncogenes and the p53 suppressor gene in seven malignant mesothelioma patients exposed to asbestos. PCR-SSCP and sequencing analyses of paraffin-embedded primary tumors Ind Health.1998;36:52-56.

141. Sekido Y. Genomic abnormalities and signal transduction dysregulation in malignant mesothelioma cells. Cancer Sci.2010;101:1-6.

142. Andujar P, Lecomte C, Renier A, et al;. Clinico-pathological features and somatic gene alterations in refractory ceramic fibre-induced murine mesothelioma reveal mineral fibreinduced mesothelioma identities. Carcinogenesis.2007;28:1599-1605. 
143. Andujar P, Wang J, Descatha A, et al;. p16 ${ }^{\mathrm{INK} 4 \mathrm{~A}}$ inactivation mechanisms in non smallcell lung cancer patients occupationally exposed to asbestos. Lung Cancer.2010;67:23-30.

144. Christensen BC, Godleski JJ, Marsit CJ, et al;. Asbestos exposure predicts cell cycle control gene promoter methylation in pleural mesothelioma. Carcinogenesis.2008;29:1555-1559.

145. Toyooka S, Toyooka KO, Maruyama R, et al;. DNA methylation profiles of lung tumors. Mol Cancer Ther.2001;1:61-67.

146. Hirao T, Bueno R, Chen CJ, Gordon GJ, Heilig E, Kelsey KT. Alterations of the p16INK4 locus in human malignant mesothelial tumors. Carcinogenesis.2002;23:11271130.

147. Wong L, Zhou J, Anderson D, Kratzke RA. Inactivation of p16INK4a expression in malignant mesothelioma by methylation. Lung Cancer.2002;38:131-136.

148. Marsit CJ, Houseman EA, Christensen BC, et al;. Examination of a CpG island methylator phenotype and implications of methylation profiles in solid tumors. Cancer Res.2006;66:10621-10629.

149. Destro A, Ceresoli GL, Baryshnikova E, et al;. Gene methylation in pleural mesothelioma: correlations with clinico-pathological features and patient's follow-up. Lung Cancer.2008;59:369-376.

150. Guled M, Lahti L, Lindholm PM, et al;. CDKN2A, NF2, and JUN are dysregulated among other genes by miRNAs in malignant mesothelioma -A miRNA microarray analysis. Genes Chromosomes Cancer.2009;48:615-623.

151. Petitjean A, Mathe E, Kato S, et al;. Impact of mutant p53 functional properties on TP53 mutation patterns and tumor phenotype: lessons from recent developments in the IARC TP53 database. Hum Mutat.2007;28:622-629.

152. Le Calvez F, Mukeria A, Hunt JD, et al;. TP53 and KRAS mutation load and types in lung cancers in relation to tobacco smoke: distinct patterns in never, former, and current smokers. Cancer Res.2005;65:5076-5083.

153. Husgafvel-Pursiainen K, Karjalainen A, Kannio A, et al;. Lung cancer and past occupational exposure to esbestos. Role of p53 and K-ras mutations. Am J Respir Cell Mol Biol.1999;20:667-674. 
1338 154. Vaslet CA, Messier NJ, Kane AB. Accelerated progression of asbestos-induced mesotheliomas in heterozygous p53 (+/-) mice. Toxicol Sci.2002;68:331-338.

155. Jean D, Thomas E, Renier A, et al;. Syntenic relationships between genomic profiles of fiber-induced murine and human malignant mesothelioma. Am J Pathol.2011;176:881894.

156. Bianchi AB, Mitsunaga S, Cheng J, et al;. High frequency of inactivating mutations in the neurofibromatosis type 2 gene (NF2) in primary malignant mesothelioma. Proc Natl Acad Sci, USA.1995;92:10854-10858.

157. Sekido Y, Pass HI, Bader S, Mew DJ, Christmas MF, Gazdar AF. Neurofibromatosis type 2 (NF2) gene is somatically mutated in mesothelioma but not in lung cancer. Cancer Res.1995;55:1227-1231.

158. Lallemand D, Curto M, Saotome I, Giovannini M, McClatchey AI. NF2 deficiency promotes tumorigenesis and metastasis by destabilizing adherens junctions. Genes Dev.2003;17:1090-1100.

159. Yi C, Troutman S, Fera D, et al;. A Tight Junction-Associated Merlin-Angiomotin Complex Mediates Merlin's Regulation of Mitogenic Signaling and Tumor Suppressive Functions. Cancer Cell.2010;19:527-540.

1355 160. Stamenkovic I, Yu Q. Merlin, a "magic" linker between extracellular cues and intracellular signaling pathways that regulate cell motility, proliferation, and survival. Curr Protein Pept Sci.2010;11:471-484.

1358 161. Tiainen M, Tammilehto L, Mattson K, Knuutila S. Nonrandom chromosomal abnormalities in malignant pleural mesothelioma. Cancer Genet Cytogenet.1988;33:251274.

162. Pyrhonen S, Tiainen M, Rautonen J, et al;. Comparison of DNA and karyotype ploidy in malignant mesothelioma. Cancer Genet Cytogenet.1992;60:8-13.

1363 163. Tiainen M, Hopman A, Moesker O, et al;. Interphase cytogenetics on paraffin sections of malignant pleural mesothelioma. A comparison to conventional karyotyping and flow

1366 164. Tiainen M, Kere J, Tammilehto L, Mattson K, Knuutila S. Abnormalities of 1367 chromosomes 7 and 22 in human malignant pleural mesothelioma: correlation between Southern blot and cytogenetic analyses. Genes Chromosomes Cancer.1992;4:176-182. 
1369 165. Tiainen M, Rautonen J, Pyrhonen S, Tammilehto L, Mattson K, Knuutila S. Chromosome number correlates with survival in patients with malignant pleural mesothelioma. Cancer Genet Cytogenet.1992;62:21-24.

1372 166. Kivipensas P, Bjorkqvist AM, Karhu R, et al;. Gains and losses of DNA sequences in malignant mesothelioma by comparative genomic hybridization. Cancer Genet Cytogenet.1996;89:7-13.

168. Ivanov SV, Miller J, Lucito R, et al;. Genomic events associated with progression of pleural malignant mesothelioma. Int J Cancer.2009;124:589-599.

169. Bueno R, De Rienzo A, Dong L, et al;. Second generation sequencing of the mesothelioma tumor genome. PLoS One.2010;5:e10612.

1382 170. Cheung M, Pei J, Pei Y, Jhanwar SC, Pass HI, Testa JR. The promyelocytic leukemia zinc-finger gene, PLZF, is frequently downregulated in malignant mesothelioma cells and contributes to cell survival. Oncogene.2010;29:1633-1640.

1385 171. Christensen BC, Houseman EA, Poage GM, et al;. Integrated Profiling Reveals a Global Correlation between Epigenetic and Genetic Alterations in Mesothelioma. Cancer Res.2010;70:5686-5694.

1388 172. Hagemeijer A, Versnel MA, Van Drunen E, et al;. Cytogenetic analysis of malignant mesothelioma. Cancer Genet Cytogenet.1990;47:1-28.

1390 173. Ribotta M, Roseo F, Salvio M, et al;. Recurrent chromosome 6 abnormalities in malignant mesothelioma. Monaldi Arch Chest Dis.1998;53:228-235.

1392 174. Mitelman F, Johansson B, Mertens F. Database of chromosome aberrations in cancer. 1393 2008

1394 175. Gisselsson D, Pettersson L, Hoglund M, et al;. Chromosomal breakage-fusion-bridge events cause genetic intratumor heterogeneity. Proc Natl Acad Sci U S A.2000;97:53575362.

176. Olofsson K, Mark J. Specificity of asbestos-induced chromosomal aberrations in shortterm cultures human mesothelial cells. Cancer Genet Cytogenet.1989;41:33-39. 
1399

1400

1401

1402

1403

1404

1405

1406

1407

1408

1409

1410

1411

1412

1413

1414

1415

1416

1417

1418

1419

1420

1421

1422

1423

1424

1425

1426

1427

1428

177. Tiainen M, Tammilehto L, Rautonen J, Tuomi T, Mattson K, Knuutila S. Chromosomal abnormalities and their correlations with asbestos exposure and survival in patients with mesothelioma. Br J Cancer.1989;60:618-626.

178. Tammilehto L, Tuomi $\mathrm{T}$, Tiainen $\mathrm{M}$, et al;. Malignant mesothelioma: clinical characteristics, asbestos mineralogy and chromosomal abnormalities of 41 patients. Eur J Cancer.1992;28A:1373-1379.

179. Bjorkqvist AM, Tammilehto L, Nordling S, et al;. Comparison of DNA copy number changes in malignant mesothelioma, adenocarcinoma and large-cell anaplastic carcinoma of the lung. Br J Cancer.1998;77:260-269.

180. Bjorkqvist AM, Wolf M, Nordling S, et al;. Deletions at 14q in malignant mesothelioma detected by microsatellite marker analysis. Br J Cancer.1999;81:1111-1115.

181. Assamaki R, Sarlomo-Rikala M, Lopez-Guerrero JA, et al;. Array comparative genomic hybridization analysis of chromosomal imbalances and their target genes in gastrointestinal stromal tumors. Genes Chromosomes Cancer.2007;46:564-576.

182. Tsou JA, Shen LY, Siegmund KD, et al;. Distinct DNA methylation profiles in malignant mesothelioma, lung adenocarcinoma, and non-tumor lung. Lung Cancer.2005;47:193204.

183. Goto Y, Shinjo K, Kondo Y, et al;. Epigenetic profiles distinguish malignant pleural mesothelioma from lung adenocarcinoma. Cancer Res.2009;69:9073-9082.

184. Tsou JA, Galler JS, Wali A, et al;. DNA methylation profile of 28 potential marker loci in malignant mesothelioma. Lung Cancer.2007;58:220-230.

185. Nymark P, Guled M, Borze I, Faisal A, Lahti L, Salmenkivi K. Integrative analysis od microRNA, mRNA and acGH dta reveals asbestos- and histology-related changes in lung cancer. In Press.

186. Ivanov SV, Goparaju CM, Lopez P, et al;. Pro-tumorigenic effects of miR-31 loss in mesothelioma. J Biol Chem.2010.

187. Pass HI, Goparaju C, Ivanov S, et al;. hsa-miR-29c* Is Linked to the Prognosis of Malignant Pleural Mesothelioma. Cancer Res.2010;70:1916-1924.

188. Murakami H, Mizuno T, Taniguchi T, et al;. LATS2 Is a Tumor Suppressor Gene of Malignant Mesothelioma. Cancer Res.2011;71:873-883. 
1429 189. Thurneysen C, Opitz I, Kurtz S, Weder W, Stahel RA, Felley-Bosco E. Functional inactivation of NF2/merlin in human mesothelioma. Lung Cancer.2009;64:140-147.

1431 190. Romagnoli S, Fasoli E, Vaira V, et al;. Identification of potential therapeutic targets in malignant mesothelioma using cell-cycle gene expression analysis. Am J Pathol.2009;174:762-770.

191. Crispi S, Fagliarone C, Biroccio A, et al;. Antiproliferative effect of Aurora kinase targeting in mesothelioma. Lung Cancer.2010;70:271-279.

1436 192. Roe OD, Anderssen E, Sandeck H, Christensen T, Larsson E, Lundgren S. Malignant pleural mesothelioma: genome-wide expression patterns reflecting general resistance mechanisms and a proposal of novel targets. Lung Cancer.2010;67:57-68.

193. Lopez-Rios F, Chuai S, Flores R, et al;. Global gene expression profiling of pleural mesotheliomas: overexpression of aurora kinases and P16/CDKN2A deletion as prognostic factors and critical evaluation of microarray-based prognostic prediction. Cancer Res.2006;66:2970-2979.

1443 194. Rubin CI, Atweh GF. The role of stathmin in the regulation of the cell cycle. J Cell Biochem.2004;93:242-250.

1445 195. Kim JY, Harvard C, You L, et al;. Stathmin is overexpressed in malignant mesothelioma. $1446 \quad$ Anticancer Res.2007;27:39-44.

1447 196. Lemmon MA, Schlessinger J. Cell signaling by receptor tyrosine kinases. $1448 \quad$ Cell.2010;141:1117-1134.

1449 197. Vintman L, Nielsen S, Berner A, Reich R, Davidson B. Mitogen-activated protein kinase expression and activation does not differentiate benign from malignant mesothelial cells. Cancer.2005;103:2427-2433.

1452 198. de Melo M, Gerbase MW, Curran J, Pache JC. Phosphorylated extracellular signal1453 regulated kinases are significantly increased in malignant mesothelioma. J Histochem Cytochem.2006;54:855-861.

1455 199. Eguchi R, Fujimori Y, Takeda H, et al;. Arsenic trioxide induces apoptosis through JNK and ERK in human mesothelioma cells. J Cell Physiol.2011;226:762-768.

1457 200. Ou WB, Hubert C, Corson JM, et al;. Targeted inhibition of multiple receptor tyrosine 1458 kinases in mesothelioma. Neoplasia.2011;13:12-22. 
Chapter ex15 new22Revised Vf(text and tables).doc

page $58 / 72$

1459 201. Ohta Y, Shridhar V, Bright RK, et al;. VEGF and VEGF type C play an important role in $1460 \quad$ angiogenesis and lymphangiogenesis in human malignant mesothelioma tumours. Br $\mathrm{J}$ $1461 \quad$ Cancer.1999;81:54-61.

1462 202. Konig J, Tolnay E, Wiethege T, Muller K. Co-expression of vascular endothelial growth 1463 factor and its receptor flt-1 in malignant pleural mesothelioma. Respiration.2000;67:36$1464 \quad 40$.

1465 203. Strizzi L, Catalano A, Vianale G, et al;. Vascular endothelial growth factor is an autocrine 1466 growth factor in human malignant mesothelioma. J Pathol.2001;193:468-475.

1467 204. Filho AL, Baltazar F, Bedrossian C, Michael C, Schmitt FC. Immunohistochemical 1468 expression and distribution of VEGFR-3 in malignant mesothelioma. Diagn $1469 \quad$ Cytopathol.2007;35:786-791.

1470 205. Lee AY, Raz DJ, He B, Jablons DM. Update on the molecular biology of malignant 1471 mesothelioma. Cancer.2007;109:1454-1461.

1472 206. Masood R, Kundra A, Zhu S, et al;. Malignant mesothelioma growth inhibition by agents that target the VEGF and VEGF-C autocrine loops. Int J Cancer.2003;104:603-610.

207. Jacobson A, Brinck J, Briskin MJ, Spicer AP, Heldin P. Expression of human hyaluronan synthases in response to external stimuli. Biochem J.2000;348:29-35.

208. Heldin P, Asplund T, Ytterberg D, Thelin S, Laurent TC. Characterization of the molecular mechanism involved in the activation of hyaluronan synthetase by plateletderived growth factor in human mesothelial cells. Biochem J.1992;283 ( Pt 1):165-170.

209. Gerwin BI, Lechner JF, Reddel RR, et al;. Comparison of production of transforming 1480 growth factor-beta and platelet-derived growth factor by normal human mesothelial cells and mesothelioma cell lines. Cancer Res.1987;47:6180-6184.

210. Versnel MA, Claessonwelsh L, Hammacher A, et al;. Human malignant mesothelioma 1483 cell lines express PDGF beta-receptors whereas cultured normal mesothelial cells express predominantly PDGF alpha-receptors. Oncogene.1991;6:2005-2011.

1485 211. Metheny-Barlow LJ, Flynn B, van Gijssel HE, Marrogi A, Gerwin BI. Paradoxical effects 1486 of platelet-derived growth factor-A overexpression in malignant mesothelioma. Antiproliferative effects in vitro and tumorigenic stimulation in vivo. Am J Respir Cell Mol Biol.2001;24:694-702. 
212. Van der Meeren A, Seddon MB, Betsholtz CA, Lechner JF, Gerwin BI. Tumorigenic conversion of human mesothelial cells as a consequence of platelet-derived growth factorA chain overexpression. Amer J Respir Cell Mol Biol.1993;8:214-221.

213. Agarwal V, Lind MJ, Cawkwell L. Targeted epidermal growth factor receptor therapy in malignant pleural mesothelioma: Where do we stand? Cancer Treat Rev.2010.

214. Hoang CD, Zhang X, Scott PD, et al;. Selective activation of insulin receptor substrate-1 and -2 in pleural mesothelioma cells: association with distinct malignant phenotypes. Cancer Res.2004;64:7479-7485.

215. Whitson BA, Kratzke RA. Molecular pathways in malignant pleural mesothelioma. Cancer Lett.2006;239:183-189.

216. Jaurand MC, Fleury-Feith J. Mesothelial cells. In: Light RW, Lee YCG, eds. Textbook of pleural diseases. Second edition. London: Hodder Arnold; 2008:27-37.

217. Lee TC, Zhang Y, Aston C, et al;. Normal human mesothelial cells and mesothelioma cell lines express insulin-like growth factor $I$ and associated molecules. Cancer Res.1993;53:2858-2864.

218. Liu Z, Klominek J. Regulation of matrix metalloprotease activity in malignant mesothelioma cell lines by growth factors. Thorax.2003;58:198-203.

219. Jagadeeswaran R, Ma PC, Seiwert TY, et al;. Functional analysis of c-Met/hepatocyte growth factor pathway in malignant pleural mesothelioma. Cancer Res.2006;66:352-361.

220. Kawaguchi K, Murakami H, Taniguchi T, et al;. Combined inhibition of MET and EGFR suppresses proliferation of malignant mesothelioma cells. Carcinogenesis.2009;30:10971105 .

221. Tolnay E, Kuhnen C, Wiethege T, König JE, Voss B, Müller KM. Hepatocyte growth factor/scatter factor and its receptor c-Met are overexpressed and associated with an increased microvessel density in malignant pleural mesothelioma. J Cancer Res Clin Oncol.1998;124:291-296.

222. Thirkettle I, Harvey P, Hasleton PS, Ball RY, Warn RM. Immunoreactivity for cadherins, HGF/SF, met, and erbB-2 in pleural malignant mesotheliomas. Histopathol.2000;36:522528. 
Chapter ex15 new22Revised Vf(text and tables).doc

page $60 / 72$

1518 223. Harvey P, Warn A, Dobbin S, et al;. Expression of HGF/SF in mesothelioma cell lines and its effects on cell motility, proliferation and morphology. Br J Cancer.1998;77:10521059.

1521 224. Mukohara T, Civiello G, Davis IJ, et al;. Inhibition of the met receptor in mesothelioma. $1522 \quad$ Clin Cancer Res.2005;11:8122-8130.

1523 225. Besson A, Robbins SM, Yong VW. PTEN/MMAC1/TEP1 in signal transduction and tumorigenesis. Eur J Biochem.1999;263:605-611.

1525 226. Daubriac J, Fleury-Feith J, Kheuang L, et al;. Malignant pleural mesothelioma cells resist anoikis as quiescent pluricellular aggregates. Cell Death and Differentiation.2009;16 1146-1155.

1528 227. Altomare DA, You H, Xiao GH, et al;. Human and mouse mesotheliomas exhibit elevated AKT/PKB activity, which can be targeted pharmacologically to inhibit tumor cell growth. Oncogene.2005;24:6080-6089.

1531 228. Suzuki Y, Murakami H, Kawaguchi K, et al;. Activation of the PI3K-AKT pathway in 1532 human malignant mesothelioma cells. Molecular Medicine Reports.2009;2:181-188.

1533 229. Clevers H. Wnt/beta-catenin signaling in development and disease. Cell.2006;127:469$1534 \quad 480$.

1535 230. Lee AY, He B, You L, et al;. Dickkopf-1 antagonizes Wnt signaling independent of beta1536 catenin in human mesothelioma. Biochem Biophys Res Commun.2004;323:1246-1250.

1537 231. He B, Lee AY, Dadfarmay S, et al;. Secreted frizzled-related protein 4 is silenced by 1538 hypermethylation and induces apoptosis in beta-catenin-deficient human mesothelioma 1539

1540 232. Batra S, Shi Y, Kuchenbecker KM, et al;. Wnt inhibitory factor-1, a Wnt antagonist, is 1541

233. Kohno H, Amatya VJ, Takeshima Y, et al;. Aberrant promoter methylation of WIF-1 and SFRP1, 2, 4 genes in mesothelioma. Oncol Rep.2010;24:423-431.

1545 234. Mazieres J, You L, He B, et al;. Wnt2 as a new therapeutic target in malignant pleural 1546 mesothelioma. Int J Cancer.2005;117:326-332. 
1547 235. Soini Y, Kinnula V, Kaarteenaho-Wiik R, Kurttila E, Linnainmaa K, Paakko P. Apoptosis

1548 and expression of apoptosis regulating proteins bcl-2, mcl-1, bcl-X, and bax in malignant mesothelioma. Clin Cancer Res.1999;5:3508-3515.

1550 236. Rippo MR, Moretti S, Vescovi S, et al;. FLIP overexpression inhibits death receptorinduced apoptosis in malignant mesothelial cells. Oncogene.2004;23:7753-7760.

1552 237. O'Kane SL, Pound RJ, Campbell A, Chaudhuri N, Lind MJ, Cawkwell L. Expression of bcl-2 family members in malignant pleural mesothelioma. Acta Oncol.2006;45:449-453.

1554 238. Jin L, Amatya VJ, Takeshima Y, Shrestha L, Kushitani K, Inai K. Evaluation of apoptosis and immunohistochemical expression of the apoptosis-related proteins in mesothelioma. Hiroshima J Med Sci.2010;59:27-33.

1558 240. Kafiri G, Thomas DM, Shepherd NA, Krausz T, Lane DP, Hall PA. p53 expression is common in malignant mesothelioma. Histopathology.1992;21:331-334.

1560 241. Ramael M, Lemmens G, Eerdekens C, et al;. Immunoreactivity for p53 protein in malignant mesothelioma and non-neoplastic mesothelium. J Pathol.1992;168:371-375.

242. Mayall FG, Goddard H, Gibbs AR. The Frequency of p53 Immunostaining in AsbestosAssociated Mesotheliomas and Non-Asbestos-Associated Mesotheliomas. Histopathology.1993;22:383-386.

243. Attanoos RL, Griffin A, Gibbs AR. The use of immunohistochemistry in distinguishing reactive from neoplastic mesothelium. A novel use for desmin and comparative evaluation with epithelial membrane antigen, p53, platelet-derived growth factor-receptor, P-glycoprotein and Bcl-2. Histopathology.2003;43:231-238.

244. Feng Z, Levine AJ. The regulation of energy metabolism and the IGF-1/mTOR pathways by the p53 protein. Trends Cell Biol.2010;20:427-434.

1571 245. Leard LE, Broaddus VC. Mesothelial cell proliferation and apoptosis. Respirology.2004;9:292-299.

1573 246. Wilson SM, Barbone D, Yang TM, et al;. mTOR mediates survival signals in malignant 1574 mesothelioma grown as tumor fragment spheroids. Am J Respir Cell Mol Biol.2008;in press.

1576 247. Singhal S, Wiewrodt R, Malden LD, et al;. Gene expression profiling of malignant mesothelioma. Clin Cancer Res.2003;9:3080-3097. 
1578 248. Lampson MA, Cheeseman IM. Sensing centromere tension: Aurora B and the regulation of kinetochore function. Trends Cell Biol.2011;21:133-140.

249. Jensen CG, Jensen LCW, Rieder CL, Cole RW, Ault JG. Long crocidolite asbestos fibers cause polyploidy by sterically blocking cytokinesis. Carcinogenesis.1996;17:2013-2021.

250. Jensen CG, Watson M. Inhibition of cytokinesis by asbestos and synthetic fibres. Cell Biol Intl.1999;23:829-840.

1584 251. Cortez BA, Machadosantelli GM. Chrysotile effects on human lung cell carcinoma in culture: 3-D reconstruction and DNA quantification by image analysis. BMC Cancer.2008;8:181.

252. Mijailovich SM, Kojic M, Tsuda A. Particle-induced indentation of the alveolar epithelium caused by surface tension forces. J Appl Physiol.2010;109:1179-1194.

253. Nymark P, Wikman H, Hienonen-Kempas T, Anttila S. Molecular and genetic changes in asbestos-related lung cancer. Cancer Lett.2008;265:1-15.

1591 254. Broaddus VC, Everitt JI, Black B, Kane AB. Non-neoplastic and neoplastic pleural endpoints following fiber exposure. J Toxicol Environ Health B Crit Rev.2011;14:153178.

1594 255. Libbus BL, Craighead JE. Chromosomal translocations with specific breakpoints in asbestos-induced rat mesotheliomas. Cancer Res.1988;48:6455-6461.

256. Ni Z, Liu YQ, Keshava N, Zhou G, Whong WZ, Ong TM. Analysis of K-ras and p53 mutations in mesotheliomas from humans and rats exposed to asbestos. Mutat Res.2000;468:87-92.

257. Unfried K, Kociok N, Roller M, Friemann J, Pott F, Dehnen W. P53 mutations in tumours induced by intraperitoneal injection of crocidolite asbestos and benzo[a]pyrene in rats. Exp Toxicol Pathol.1997;49:181-187.

1602 258. Unfried K, Schürkes C, Abel J. Distinct spectrum of mutations induced by crocidolite asbestos : clue for 8-hydroxydeoxyguanosine-dependent mutagenesis in vivo. Cancer Res.2002;62:99-104.

1605 259. Schurkes C, Brock W, Abel J, Unfried K. Induction of 8-hydroxydeoxyguanosine by man 1606 made vitreous fibres and crocidolite asbestos administered intraperitoneally in rats. Mutat Res.2004;553:59-65. 
Chapter ex15 new22Revised Vf(text and tables).doc

page $63 / 72$

1608 260. Altomare DA, Menges CW, Pei J, et al;. Activated TNF-alpha/NF-kappaB signaling via down-regulation of Fas-associated factor 1 in asbestos-induced mesotheliomas from Arf knockout mice. Proc Natl Acad Sci U S A.2009;106:3420-3425.

1611 261. Burmeister B, Schwerdtle T, Poser I, et al;. Effects of asbestos on initiation of DNA 1612 damage, induction of DNA-strand breaks, P53-expression and apoptosis in primary, SV40-transformed and malignant human mesothelial cells. Mutat Res.2004;558:81-92.

1614 262. Chen Q, Marsh J, Ames B, Mossman B. Detection of 8-oxo-2'-deoxyguanosine, a marker 1615 of oxidative DNA damage, in culture medium from human mesothelial cells exposed to crocidolite asbestos. Carcinogen.1996;17:2525-2527.

1617 263. Fung H, Kow YW, Van Houten B, Mossman BT. Patterns of 8-hydroxydeoxyguanosine 1618 formation in DNA and indications of oxidative stress in rat and human pleural mesothelial cells after exposure to crocidolite asbestos. Carcinogenesis.1997;18:825-832.

264. Nygren J, Suhonen S, Norppa H, Linnainmaa K. DNA damage in bronchial epithelial and mesothelial cells with and without associated crocidolite asbestos fibers. Environ Mol

265. Jaurand MC, Kheuang L, Magne L, Bignon J. Chromosomal changes induced by chrysotile fibres or benzo(3-4)pyrene in rat pleural mesothelial cells. Mutat Res.1986;169:141-148.

266. Renier A, Levy F, Pilliere F, Jaurand MC. Uncheduled DNA synthesis in rat pleural mesothelial cells treated with mineral fibres or benzo[a]pyrene. Mutat Res.1990;241:361367.

267. Fung H, Kow YW, Van Houten B, et al;. Asbestos increases mammalian APendonuclease gene expression, protein levels, and enzyme activity in mesothelial cells. Cancer Res.1998;58:189-194.

268. Janssen YMW, Heintz NH, Marsh JP, Borm PJA, Mossman BT. Induction of c-fos and cjun proto-oncogenes in target cells of the lung and pleura by carcinogenic fibers. Amer $\mathbf{J}$ Respir Cell Mol Biol.1994;11:522-530.

269. Timblin CR, Janssen YWM, Mossman BT. Transcriptional activation of the protooncogene c-jun by asbestos and $\mathrm{H} 2 \mathrm{O} 2$ is directly related to increased proliferation and transformation of tracheal epithelial cells. Cancer Res.1995;55:2723-2726. 
Chapter ex15 new22Revised Vf(text and tables).doc

page 64/72

1638 270. Zanella CL, Timblin CR, Cummins A, et al;. Asbestos-induced phosphorylation of

1639 epidermal growth actor receptor is linked to c-fos and apoptosis. Am J

$1640 \quad$ Physiol.1999;277:L684-L693.

1641 271. Berken A, Abel J, Unfried K. beta1-integrin mediates asbestos-induced phosphorylation

1642 of AKT and ERK1/2 in a rat pleural mesothelial cell line. Oncogene.2003;22:8524-8528.

1643

1644 
Chapter ex15 new22Revised Vf(text and tables).doc

page $65 / 72$

1645

1646

1647

Legend to figure

1648

1649 Figure 15-1. Multistage Development of Asbestos-Induced Mesothelioma

1650 Adapted from Shukla et al., 2003 [76]; Nymark et al., 2008 [253]; Pacurari et al., 2010 [114];

1651 Broaddus et al., 2011 [254].

1652 
Tables

Table 22-1. Molecular alterations in mesothelial tissue and malignant mesothelioma developed in asbestos-exposed animals

\begin{tabular}{|c|c|c|c|}
\hline Reference & Animal, type of experiment & Fiber type & Molecular alteration \\
\hline & Rat & & \\
\hline Libbus et al., 1988 [255] & $\begin{array}{l}\text { Rat, i.p. administration } \\
\text { Chromosome analysis in MM. }\end{array}$ & $\begin{array}{l}\text { Crocidolite } \\
\text { Chrysotile }\end{array}$ & $\begin{array}{l}\text { Loss of chromosomes X, 8, 16, } 18 \text { and } 20 \text {. } \\
\text { Translocations involving } 5,10 \text { and } 13 \text {, repeated } \\
\text { points. }\end{array}$ \\
\hline Ni et al., 2000 [256] & $\begin{array}{l}\text { Rat, i.p. administration. } \\
\text { Investigation of } \mathrm{p} 53 \text { (exons 5-8), } \\
\text { and } K \text {-ras (exons } 1,2 \text { ) mutations } \\
\text { in MM. }\end{array}$ & Crocidolite & No mutation detected. \\
\hline $\begin{array}{l}\text { Unfried et al., } 1997 \\
\text { [257] }\end{array}$ & $\begin{array}{l}\text { Rat, i.p. administration. } \\
\text { Investigation of p53 mutations in } \\
\text { MM. }\end{array}$ & Crocidolite & $\begin{array}{l}\text { No mutation detected in p53 while numerous base } \\
\text { substitution were found in } \mathrm{B}[\mathrm{a}] \mathrm{P} \text {-treated animals. }\end{array}$ \\
\hline $\begin{array}{l}\text { Unfried et al., } 2004 \\
\text { [258] }\end{array}$ & Big Blue rat, i.p. administration. & Crocidolite & $\begin{array}{l}\text { Significantly enhanced mutation rate of lacI gene } \\
\text { from omenta } 12 \text { and } 24 \text { weeks post-exposure*. }\end{array}$ \\
\hline $\begin{array}{l}\text { Schürkes et al., } 2004 \\
\text { [259] }\end{array}$ & Rat, i.p. administration. & Crocidolite & $\begin{array}{l}\text { Significantly enhanced level of } 8-\mathrm{OHdG} \text { in DNA } \\
\text { from omenta } 10-20 \text { weeks post treatment. }\end{array}$ \\
\hline
\end{tabular}




\begin{tabular}{|c|c|c|c|}
\hline & Mice & & \\
\hline Vaslet et al., 2002 [154] & $\begin{array}{l}\text { Mice, Trp53 heterozygous, i.p. } \\
\text { administration. Gene analysis. }\end{array}$ & Crocidolite & LOH at the $\operatorname{Trp} 53$ locus. \\
\hline $\begin{array}{l}\text { Fleury-Feith et al., } 2003 \\
\text { [23] }\end{array}$ & $\begin{array}{l}\text { Mice, } N f 2 \text { heterozygous, i.p. } \\
\text { administration. Gene analysis. }\end{array}$ & Crocidolite & $\mathrm{LOH}$ at the $N f 2$ locus. \\
\hline $\begin{array}{l}\text { Altomare et al., } 2005 \\
\text { [51] }\end{array}$ & $\begin{array}{l}\text { Mice, } N f 2 \text { heterozygous, i.p. } \\
\text { administration. Gene analysis. }\end{array}$ & Crocidolite & $\mathrm{LOH}$ at the $N f 2$ locus. Deletion $I N K 4$ locus. \\
\hline Lecomte et al., 2005 [52] & $\begin{array}{l}\text { Mice, } N f 2 \text { heterozygous, i.p. } \\
\text { administration. Gene analysis. }\end{array}$ & Crocidolite & LOH at the $N f 2$ locus. Deletion INK 4 locus. \\
\hline $\begin{array}{l}\text { Altomare et al., } 2009 \\
\text { [260] }\end{array}$ & $\begin{array}{l}\text { Mice, Arf heterozygous, i.p. } \\
\text { administration. Gene analysis. }\end{array}$ & Crocidolite & $\begin{array}{l}\text { LOH at the Arf locus. Hemizygous loss of Fafl } \\
\text { (Fas-associated factor } 1 \text { ). }\end{array}$ \\
\hline
\end{tabular}

i.p. : intraperitoneal

LOH : Loss Of Heterozygozity

* G to T predominant (29\%) followed by deletion (26\%), G to A (20\%), G to C (12\%), A to T (6\%), A to G and insertion (3\%), while controls spontaneous mutations were $\mathrm{G}$ to $\mathrm{T} 19 \%$, deletion $5 \%, \mathrm{G}$ to $\mathrm{A} 57 \%$, G to $\mathrm{C} 14 \%$, A to $\mathrm{T}$ and $\mathrm{A}$ to $\mathrm{G} 0 \%$ and insertion $5 \%$ 
Table 22-2. Molecular alterations in mesothelial cells in culture treated with asbestos fibers

\begin{tabular}{|c|c|c|c|}
\hline Reference & Cells. Type of experiment & Fiber type & $\begin{array}{l}\text { Molecular alteration in comparison with untreated } \\
\text { or sham cells }\end{array}$ \\
\hline & Human & & \\
\hline Lechner et al., 1985 [120] & $\begin{array}{l}\text { Normal cells. Karyotype analysis of } \\
\text { cells after several passages. }\end{array}$ & Amosite & $\begin{array}{l}\text { Numerical and structural chromosomal abnormalities } \\
\text { from passage } 5 \text {. }\end{array}$ \\
\hline $\begin{array}{l}\text { Olofsson et al., } 1989 \\
\text { [176] }\end{array}$ & $\begin{array}{l}\text { Normal cells. Karyotype analysis (G } \\
\text { banding). }\end{array}$ & $\begin{array}{l}\text { Crocidolite } \\
\text { Chrysotile } \\
\text { Amosite }\end{array}$ & $\begin{array}{l}\text { Non random aneuploidy, deletion, translocations, } \\
\text { inversions (but not breaks, dicentrics, fragments, } \\
\text { polyploidization). }\end{array}$ \\
\hline Pelin et al., 1995 [46] & $\begin{array}{l}\text { Normal cells from different } \\
\text { donors***. Chromosomal } \\
\text { aberrations in metaphases in six } \\
\text { donors. }\end{array}$ & Amosite & $\begin{array}{l}\text { Increased chromosome breakage in four cases. } \\
\text { Independent of GSTM1 status. }\end{array}$ \\
\hline $\begin{array}{l}\text { Burmeister et al., } 2004 \\
\text { [261] }\end{array}$ & $\begin{array}{l}\text { Normal cells and human Met-5A. } \\
\text { DNA breakage (comet assay, } \\
\text { quantification of DNA-strand breaks } \\
\text { and Fpg-sensitive sites by alkaline } \\
\text { unwinding*). }\end{array}$ & $\begin{array}{l}\text { Crocidolite } \\
\text { Chrysotile }\end{array}$ & $\begin{array}{l}\text { DNA breakage in both assays, but no increase in Fpg- } \\
\text { sensitive sites. } \\
\text { No effect on MeT-5A cells. }\end{array}$ \\
\hline Poser et al., 2004 [48] & $\begin{array}{l}\text { Normal cells. Micronucleus assay } \\
\text { and kinetochore analysis. }\end{array}$ & $\begin{array}{l}\text { Crocidolite } \\
\text { Chrysotile }\end{array}$ & $\begin{array}{l}\text { Micronucleus formation, chromosome breakage. Role } \\
\text { of } \operatorname{ROS}^{* *} \text { and metals. }\end{array}$ \\
\hline
\end{tabular}




\begin{tabular}{|c|c|c|c|}
\hline Chen et al., 1996 [262] & $\begin{array}{l}\text { MeT-5A. Formation of } 8 \text {-oxo-2'- } \\
\text { deoxyguanosine released in the } \\
\text { culture medium (HPLC). }\end{array}$ & Crocidolite & Increased level of of 8-oxo-2'-deoxyguanosine. \\
\hline Fung et al., 1997 [263] & $\begin{array}{l}\text { MeT-5A. Formation of } 8-\mathrm{OH}-\mathrm{dG} \text { in } \\
\text { DNA (HPLC). }\end{array}$ & Crocidolite & Decreased level of 8-OH-dG. \\
\hline $\begin{array}{l}\text { Jensen and Watson, } 1999 \\
\text { [250] }\end{array}$ & $\begin{array}{l}\text { MeT-5A. High-resolution time-lapse } \\
\text { microscopy. }\end{array}$ & $\begin{array}{l}\text { Crocidolite } \\
\text { Chrysotile }\end{array}$ & $\begin{array}{l}\text { Delayed cytokinesis. Formation of bi- multinucleated } \\
\text { cells. }\end{array}$ \\
\hline \multirow[t]{2}{*}{ Nygren et al., 2004 [264] } & $\begin{array}{l}\text { MeT-5A. DNA breakage (comet } \\
\text { assay). }\end{array}$ & Crocidolite & $\begin{array}{l}\text { Increased DNA breakage, more pronounced in cells } \\
\text { associated with fibers than in cells without fibers. }\end{array}$ \\
\hline & Rat & & \\
\hline Jaurand et al., 1986 [265] & $\begin{array}{l}\text { Pleural mesothelial cells. } \\
\text { Morphological study of metaphases. }\end{array}$ & Chrysotile & Increased chromosome breakage. \\
\hline Achard et al., 1987 [42] & $\begin{array}{l}\text { Pleural mesothelial cells. Sister } \\
\text { chromatid exchanges. }\end{array}$ & Crocidolite & Increased sister chromatid exchanges. \\
\hline Wang et al., 1987 [43] & $\begin{array}{l}\text { Pleural mesothelial cells. } \\
\text { Ultrastructural study of metaphases. }\end{array}$ & $\begin{array}{l}\text { Crocidolite } \\
\text { Chrysotile }\end{array}$ & $\begin{array}{l}\text { Polyploidization, chromosome deformities } \\
\text { (vacuolization). }\end{array}$ \\
\hline Renier et al., 1990 [266] & $\begin{array}{l}\text { Pleural mesothelial cells. DNA } \\
\text { repair (unscheluled DNA synthesis). }\end{array}$ & Chrysotile & Increased DNA repair. \\
\hline
\end{tabular}




\begin{tabular}{|c|c|c|c|}
\hline Yegles et al., 1993 [44] & $\begin{array}{l}\text { Pleural mesothelial cells. } \\
\text { Morphological study of mitotic cells. }\end{array}$ & $\begin{array}{l}\text { Crocidolite } \\
\text { Chrysotile }\end{array}$ & $\begin{array}{l}\text { Increased aneuploidy and few structural chromosomal } \\
\text { abnormalities. Increased anaphase/telophase } \\
\text { abnormalities. }\end{array}$ \\
\hline Dong et al., 1994 [40] & $\begin{array}{l}\text { Pleural mesothelial cells. DNA } \\
\text { repair (unscheluled DNA synthesis). }\end{array}$ & $\begin{array}{l}\text { Crocidolite } \\
\text { Chrysotile }\end{array}$ & Increased DNA repair. Partial involvement of ROS. \\
\hline Dong et al., 1995 [41] & $\begin{array}{l}\text { Pleural mesothelial cells. DNA } \\
\text { repair (poly(ADP-ribose) synthesis). }\end{array}$ & $\begin{array}{l}\text { Crocidolite } \\
\text { Chrysotile }\end{array}$ & Increased DNA repair. Partial involvement of ROS. \\
\hline Yegles et al., 1995 [47] & $\begin{array}{l}\text { Pleural mesothelial cells. } \\
\text { Morphological study of mitotic cells. }\end{array}$ & $\begin{array}{l}\text { Crocidolite } \\
\text { Chrysotile } \\
\text { Amosite }\end{array}$ & Induction of abnormal anaphases and telophases. \\
\hline Fung et al., 1997 [263] & $\begin{array}{l}\text { Pleural mesothelial cells. Formation } \\
\text { of } 8-\mathrm{OH}-\mathrm{dG} \text { in DNA (HPLC) }\end{array}$ & Crocidolite & Increased level of 8-OH-dG. \\
\hline Levresse et al., 1997 [34] & $\begin{array}{l}\text { Pleural mesothelial cells. Cell cycle } \\
\text { analysis. }\end{array}$ & $\begin{array}{l}\text { Crocidolite } \\
\text { Chrysotile }\end{array}$ & $\begin{array}{l}\text { G2/M accumulation. G0/G1 accumulation and time- } \\
\text { dependent p53 and p21 expression (chrysotile). Delay } \\
\text { in the G1/S transition paralleling a low rate of p53 } \\
\text { expression (crocidolite). }\end{array}$ \\
\hline Fung et al., 1998 [267] & $\begin{array}{l}\text { Pleural mesothelial cells, induction } \\
\text { de l'enzyme apurinic/apyrimidinic } \\
\text { endonuclease. }\end{array}$ & Crocidolite & Increased level (mRNA and protein). \\
\hline
\end{tabular}




\section{Rabbit}

Pleural mesothelial cells. DNA

Liu et al., 2000 [37] breakage (alkaline unwinding ethidium bromide fluorometric

DNA breakage. Cell cyle arrest in G2/M. Phagocytosis reduction by cytochalasin reduces DNA breakage. assay).

Met-5A : an SV40-transformed human mesothelial cell line.

ROS : Reactive Oxygen Species

* Fpg protein, which recognizes oxidized bases such as 8-oxo-guanine, is used as indicative of oxidative DNA-base modifications.

** Reduction of micronucleus formation by antioxidants (metal chelators and ROS scavengers). ROS produced by fibers (crocidolite) and phagocytosis.

*** The glutathione S-transferase M1 (GSTM1) genotypes of the patients were determined. 
Table 22-3. Activation of signaling pathways in mesothelial cells in culture exposed to asbestos fibers

\begin{tabular}{|c|c|c|c|}
\hline Reference & Cells/Experiment & Fiber type & $\begin{array}{l}\text { Signaling response in comparison with untreated } \\
\text { cells }\end{array}$ \\
\hline $\begin{array}{l}\text { Janssen et al., } 1994 \\
\text { [268] }\end{array}$ & Pleural mesothelial cells from rat. & $\begin{array}{l}\text { Crocidolite } \\
\text { Chrysotile }\end{array}$ & Increased mRNA expression of c-fos and c-jun. \\
\hline $\begin{array}{l}\text { Timblin et al., } 1998 \\
\text { [269] }\end{array}$ & Pleural mesothelial cells from rat. & Crocidolite & $\begin{array}{l}\text { Increased mRNA and protein expression of c-fos } \\
\text { and c-jun. }\end{array}$ \\
\hline $\begin{array}{l}\text { Zanella et al., } 1999 \\
\text { [270] }\end{array}$ & Pleural mesothelial cells from rat. & Crocidolite & $\begin{array}{l}\text { Increased expression of mRNA c-fos via } \\
\text { enhancement of EGFR level. }\end{array}$ \\
\hline $\begin{array}{l}\text { Berken et al., } 2003 \\
\text { [271] }\end{array}$ & $\begin{array}{l}\text { Pleural mesothelial cell line non } \\
\text { tumorigenic (4/4) from rat. }\end{array}$ & Crocidolite & $\begin{array}{l}\text { Activation of Erk } 1 / 2 \text { and Akt in a } \beta \text {-integrin } \\
\text { dependent manner. }\end{array}$ \\
\hline $\begin{array}{l}\text { Altomare et al., } 2009 \\
\text { [260] }\end{array}$ & $\begin{array}{l}\text { Culture of mesothelioma cells } \\
\text { from mesothelioma form } \\
\text { heterozygous } A r f^{+/-} \text {mice i.p. } \\
\text { administration. }\end{array}$ & Crocidolite & $\begin{array}{l}\text { Regulation of NF- } \kappa \mathrm{B} \text { dependent on Fafl expression } \\
\text { in response to TNF- } \alpha \text {. Upregulated in cell showing } \\
\text { loss of Fafl (see Table 22-1). }\end{array}$ \\
\hline
\end{tabular}

Met-5A : a SV40-transformed human mesothelial cell line. 